\title{
13. SITES 635 AND 636: NORTHEAST PROVIDENCE CHANNEL ${ }^{1}$
}

\author{
Shipboard Scientific Party ${ }^{2}$
}

\section{HOLE 635A}

Date occupied: 9 March 1985, 0251 EST

Date departed: 9 March 1985, 1540 EST

Time on hole: $12 \mathrm{hr}, 49 \mathrm{~min}$

Position: $25^{\circ} 25.13^{\prime} \mathrm{N}, 77^{\circ} 19.92^{\prime} \mathrm{W}$

Water depth (sea level; corrected $\mathrm{m}$, echo-sounding, including $7.4^{\circ}$ slope correction): 3448

Water depth (rig floor; corrected $\mathrm{m}$, echo-sounding): $\mathbf{3 4 5 8 . 5}$

Bottom felt (m, drill pipe): 3445.3

Total depth (m): 3465.4

Penetration (m): 20.1

Number of cores: 3

Total length of cored section (m): 20.1

Total core recovered $(\mathrm{m}): 6.2$

Core recovery (\%): 30.8

Oldest sediment cored:

Depth sub-bottom (m): 20.1

Nature: limestone rubble

${ }^{1}$ Austin, J. A., Jr., Schlager, W., Palmer, A. A., et al., 1986. Proc., Init. Repts. (Pt. A), ODP, 101.

2 James A. Austin Jr. (Co-Chief Scientist), Institute for Geophysics, University of Texas at Austin, Austin, TX 78751; Wolfgang Schlager (Co-Chief Scientist), Rosenstiel School of Marine and Atmospheric Sciences, Miami, FL 33149 (current address: Vrije Universiteit, Instituut v. Aardwetenschappen, Postbus 7161, 1007 MC Amsterdam, Netherlands); Amanda A. Palmer, Staff Scientist, Ocean Drilling Program, Texas A\&M University, College Station, TX 77843; Paul A. Comet, The University, Newcastle-Upon-Tyne, Newcastle, United Kingdom (current address: Core Labs Singapore, 24A-Lim Teck Boo Rd., Singapore 1953); André Droxler, Rosenstiel School of Marine and Atmospheric Sciences, Miami, FL 33149 (current address: Department of Geology, University of South Carolina, Columbia, SC 29208); Gregor Eberli, Geologisches Institut, ETH-Zentrum, Zürich, Switzerland (current address: Fisher Island Station, University of Miami, Miami, FL 33139); Eric Fourcade, Laboratoire de Stratigraphie, Université Pierre et Marie Curie, 4 Place Jussieu 75230, Paris Cedex 05, France; Raymond Freeman-Lynde, Department of Geology, University of Georgia, Athens, GA 30602; Craig S. Fulthorpe, Department of Geological Sciences, Northwestern University, Evanston, IL 60201; Gill Harwood, Department of Geology, The University, Newcastle-Upon-Tyne, NE1 7RU United Kingdom; Gerhard Kuhn, Geologisches Institut Göttingen, Federal Republic of Germany (current address: Alfred Wegener Institut für Polarforschung, Columbus Center, D-2850 Bremerhaven, West Germany); Dawn Lavoie, NORDA Code 363, Seafloor Geosciences Division, NSTL, MS 39529; Mark Leckie, Woods Hole Oceanographic Institution, Woods Hole, MA 02543 (current address: Department of Geology and Geography, University of Massachusetts, Amherst, MA 01003); Allan J. Melillo, Department of Geological Sciences, Rutgers University, New Brunswick, NJ 08903 (current address: Chevron U.S.A., New Orleans, LA 70114); Arthur Moore, Marathon Oil Company, P.O. Box 269, Littleton, CO 80160; Henry T. Mullins, Department of Geology, Syracuse University, Syracuse, NY 13210; Christian Ravenne, Institut Français du Pétrole, B.P. 311, 92506 Rueil Malmaison Cedex, France; William W. Sager, Department of Oceanography, Texas A\&M University, College Station, TX 77843; Peter Swart, Fisher Island Station, University of Miami, Miami, FL 33139 (current address: Marine Geology and Geophysics, Rosenstiel School of Marine and Atmospheric Sciences, Miami, FL 33149); Joost W. Verbeek, Dutch Geological Survey, P.O. Box 157, 2000 A.D. Haarlem, Netherlands; David K. Watkins, Department of Geology, University of Nebraska, Lincoln, NE 68588; Colin Williams, Borehole Research Group, Lamont-Doherty Geological Observatory, Palisades, NY 10964.
Age: Pleistocene(?) (Late Cretaceous for limestone clasts)

Measured velocity $(\mathrm{km} / \mathrm{s}): 1.85$ (from multichannel seismic line 94 of Sheridan et al., 1981)

\section{HOLE 635B}

Date occupied: 9 March 1985, 1730 EST

Date departed: 11 March 1985, 1730 EST

Time on hole: 2 days

Position: $25^{\circ} 25.18^{\prime} \mathrm{N}, 77^{\circ} 19.98^{\prime} \mathrm{W}$

Water depth (sea level; corrected $\mathrm{m}$, echo-sounding, including $7.7^{\circ}$ slope correction): 3470

Water depth (rig floor; corrected m, echo-sounding): 3480.5

Bottom felt (m, drill pipe): $\mathbf{3 4 8 3 . 3}$

Total depth (m): 3601

Penetration (m): 117.7

Number of cores: 14

Total length of cored section (m): 117.7

Total core recovered $(\mathrm{m}): 31.2$

Core recovery $(\%): 26.5$

Oldest sediment cored:

Depth sub-bottom (m): 117.7

Nature: nannoplankton marl with debris flows

Age: late Albian

Measured velocity $(\mathrm{km} / \mathrm{s}): 3.3$ (average of Hamilton Frame measurements on out-of-liner samples)

\section{HOLE 636A}

Date occupied: 11 March 1985, 2100 EST

Date departed: 13 March 1985, 1230 EST

Time on hole: 1 day, $15 \mathrm{hr}, 30 \mathrm{~min}$

Position: $25^{\circ} 25.11^{\prime} \mathrm{N}, 77^{\circ} 18.35^{\prime} \mathrm{W}$

Water depth (sea level; corrected m, echo-sounding): 3573

Water depth (rig floor; corrected $\mathrm{m}$, echo-sounding): 3583.5

Bottom felt (m, drill pipe): 3581

Total depth (m): 3602

Penetration (m): 21

Number of cores: 2

Total length of cored section (m): 21

Total core recovered $(\mathrm{m}): 0.1$

Core recovery $(\%): 0.5$

Oldest sediment cored:

Depth sub-bottom (m): 21

Nature: limestone

Age: Neogene

Measured velocity $(\mathrm{km} / \mathrm{s}): 5$ (based on comparison with regional seismic results) 
Principal results: Sites 635 and 636 in the Northeast Providence Channel (a branch of Great Bahama Canyon) were occupied from 10 through 13 March 1985 . Hole $635 \mathrm{~A}$ is located at $25^{\circ} 25.13^{\prime} \mathrm{N}, 77^{\circ} 19.92^{\prime} \mathrm{W}$, in $3448 \mathrm{~m}$ water depth. It represents an unsuccessful attempt to spud in. Hole $635 \mathrm{~B}$ is farther downslope at $25^{\circ} 25.18^{\prime} \mathrm{N}, 77^{\circ} 19.98^{\prime} \mathrm{W}$, in $3470 \mathrm{~m}$ water depth. Site 636 could not be spudded in.

Hole 635B recovered the following sequence: (1) Unit I, 0-2 m sub-bottom, calcareous ooze and foraminifer-pteropod sand, late Pleistocene to Holocene in age; (2) Unit II, 2-61 m sub-bottom, calcareous ooze and chalk of Pliocene and Pleistocene age with detrital limestones and chalk (debris flows and turbidites?) of CenomanianTuronian age; no orderly succession of ages and no undisturbed contacts between different lithologies were observed; and (3) Unit III, 61-118 m sub-bottom; slightly argillaceous chalk and limestone with alternations of dark, organic-rich and light, carbonate-rich intervals; intercalations of muddy debris flows and slump folds, late Albian in age.

Based on borehole data and seismic profiles, Unit II is interpreted as one or more slump masses, probably derived from the northern flank of the canyon and emplaced in the late Tertiary. Unit III is in place and consists of bathyal sediments that reflect short-term fluctuations of oxygen levels characteristic of the mid-Cretaceous. Some of the rocks resemble the Cenomanian marly chalks overlying the shallow-water carbonates and evaporites at Site 627. At Site 635, a prominent seismic reflector with a velocity jump from 2.9 to $4.9 \mathrm{~km} / \mathrm{s}$ lies 70-90 m below the total depth of Hole 635B. As at Site 627, this reflector may indicate the top of a Cretaceous shallow-water platform.

The organic-rich layers in Unit III contain approximately 1\%-6\% total organic carbon and represent immature oil-and-gas-prone source rocks.

\section{OPERATIONS SUMMARY}

\section{Site 635}

\section{Hole 635A}

The JOIDES Resolution left Site 634 for BAH-3-A on the opposite flank of Northeast Providence Channel at $1845 \mathrm{hr}, 8$ March (Fig. 3, Site 634 chapter). The ship transited at 1.0-1.5 kt in dynamic-positioning mode with thrusters extended and with approximately $2300 \mathrm{~m}$ of pipe in the water. After some confusion about the exact location of BAH-3-A, the ship slowly approached the proper location at $0245 \mathrm{hr}, 9 \mathrm{March}$. A beacon was dropped at $0251 \mathrm{hr}$, but side echoes forced a move approximately $275 \mathrm{~m}$ downslope at $0410 \mathrm{hr}$. Fortunately, it was not necessary to deploy a second beacon for this maneuver. The water depth at the new location was $3407 \mathrm{~m}$ (uncorr.), $3419 \mathrm{~m}$ (corr.), and $3448 \mathrm{~m}$ including a correction for a $7.4^{\circ}$ slope estimated from regional seismic line 334 (Fig. 3, Site 634 chapter). The depth from the rig floor was therefore $3458.5 \mathrm{~m}$. The position of Hole $635 \mathrm{~A}$ was established as $25^{\circ} 25.114-140^{\prime} \mathrm{N}, 77^{\circ} 19.905-$ $931^{\prime} \mathrm{W}$ (a range based on good SATNAV fixes collected while at this location).

A successful mud-line rotary core was collected at $0945 \mathrm{hr}$ from a depth of $3445.3 \mathrm{~m}$ below the rig floor. However, only two more short rotary cores could be collected to a sub-bottom depth of $20.1 \mathrm{~m}$ before an obstruction forced abandonment of Hole $635 \mathrm{~A}$. The mud line was cleared at this location at $1540 \mathrm{hr}$, $9 \mathrm{March}$, in order to move upslope approximately $180 \mathrm{~m}$ for a second spud-in attempt.

\section{Hole 635B}

Hole $635 \mathrm{~B}$ used the same beacon for dynamic positioning as Hole $635 \mathrm{~A}$, and a spud-in attempt was begun at $1730 \mathrm{hr}, 9$ March. The water depth was $3434 \mathrm{~m}$ (corr.), and $3470 \mathrm{~m}$ including a slope correction of $7.7^{\circ}$. The position of Hole 635B was established as $25^{\circ} 25.118-246^{\prime} \mathrm{N}, 77^{\circ} 19.915-20.018^{\prime} \mathrm{W}$ (from a range of SATNAV fixes obtained on site). At $2230 \mathrm{hr}$, the mud line was tagged at a depth of $3483.5 \mathrm{~m}$ below the rig floor. Over the next $33.5 \mathrm{hr}, 13$ rotary cores were obtained to a sub-bottom depth of $113.7 \mathrm{~m}$. Core recovery over this interval was $24.5 \%$. However, while trying to retrieve Core 635B-14R (113.7-117.7 m sub-bottom), the core barrel stuck inside the drill string, and all efforts to free it during the afternoon of 11 March failed. The decision was then made to abandon Hole 635B and to retrieve the core barrel by pulling the bottom-hole assembly (BHA) to the surface. The mud line was cleared at this location by $1730 \mathrm{hr}$, and the JOIDES Resolution left Hole 635B for Site 636 in dynamic-positioning mode while continuing to pull out of the hole $(\mathrm{POOH})$ at $1900 \mathrm{hr}, 11 \mathrm{March}$.

\section{Site 636}

The JOIDES Resolution approached Site 636, the last site of Leg 101, in dynamic-positioning mode from Hole 635B approximately $1.5 \mathrm{n}$. mi to the west (see Fig. 3, Site 634 chapter). Site 636 is located on regional seismic line 334, in the axis of Northeast Providence Channel (see "Seismic Stratigraphy" section, Site 634 chapter). A beacon was dropped at $2100 \mathrm{hr}, 11 \mathrm{March}$. The water depth at the location was $3559 \mathrm{~m}$ (uncorr.) and $3573 \mathrm{~m}$ (corr.), for a rig-floor depth of $3583.5 \mathrm{~m}$. The final Site $636 \mathrm{po-}$ sition was established as $25^{\circ} 25.043-174^{\prime} \mathrm{N}, 77^{\circ} 18.121-581^{\prime} \mathrm{W}$ (from the range of good SATNAV fixes on location). During the remainder of 11 March and into $12 \mathrm{March}$, operations were centered on recovering Core 635B-14R from the BHA and replacing a worn rotary bit. The core barrel came on deck before midnight, but it could not be removed from the rest of the string until $0400 \mathrm{hr}, 12 \mathrm{March}$. The string was then prepared for running in the hole (RIH), but the bottom was not tagged until $1515 \mathrm{hr}$ at a rig-floor depth of $3581 \mathrm{~m}$. In an effort to save time, permission was obtained to wash through the sediments overlying the inferred shallow-water platform top at this location. The first wash core of Hole 636 came aboard at $1915 \mathrm{hr}$, and a second rotary core was retrieved at $0123 \mathrm{hr}, 13 \mathrm{March}$. Poth contained small fragments of Neogene limestones presumably composing part of the canyon fill. After the second core, a lack of time forced the decision to terminate drilling operations. The JOIDES Resolution got under way for Miami at $1230 \mathrm{hr}, 13 \mathrm{March}$.

The coring summary for Sites 635 and 636 appears in Table 1.

\section{SEDIMENTOLOGY}

Two holes were drilled at Site 635 . Hole 635A penetrated $20.1 \mathrm{~m}$, with $6.1 \mathrm{~m}(30 \%)$ of recovery. Hole $635 \mathrm{~B}$ penetrated $117.7 \mathrm{~m}$, with $31.6 \mathrm{~m}(27 \%)$ of recovery.

Three units are distinguished at Site 635: Unit I and part of Unit II were recovered from Hole 635A; all three units were recovered at Hole $635 \mathrm{~B}$, although Unit $\mathrm{I}$ is much thinner $(10.6 \mathrm{~m}$ at Hole 635A, $2.3 \mathrm{~m}$ at Hole 635B).

\section{Unit I (0-10.6/2.3 m sub-bottom, Cores 635A-1R to 635A-2R; Sample 635B-1R-2, $80 \mathrm{~cm}$ )}

In Hole 635A, Unit $\mathrm{I}$ is present as an alternation of a light gray (10YR $7 / 2$ and $7 / 1)$, gray (10YR $8 / 1)$, and pale brown (10YR 6/3) periplatform carbonate ooze and graded, unlithified grainstone layers. The layer thickness varies from 5 to $90 \mathrm{~cm}$. Grainstones usually range from medium to coarse carbonate sand. At the base of the thicker layers, very coarse sand can be observed with a few granules and possible mud balls. Most of the sands, which are derived from a shallow-water carbonate platform, consist of Homotrema, Halimeda, skeletal debris, miliolids, and echinoid spines. Some planktonic foraminifers and pteropods are also present. Unit I is early to late Pleistocene in age (see "Biostratigraphy" section, this chapter).

In Hole 635B, Unit I consists of a very pale brown (10YR 7/3) to light gray (10YR 7/1) periplatform carbonate ooze alternating with layers of light gray (5Y 7/1) unlithified packstone and grainstone rich in planktonic foraminifers and pteropods, as well 
Table 1. Coring summary, Sites 635 and 636.

\begin{tabular}{|c|c|c|c|c|c|c|c|}
\hline $\begin{array}{l}\text { Core } \\
\text { no. }\end{array}$ & $\begin{array}{l}\text { Core } \\
\text { type }^{a}\end{array}$ & $\begin{array}{l}\text { Date } \\
\text { (Mar. } \\
\text { 1985) }\end{array}$ & Time & $\begin{array}{l}\text { Sub-bottom } \\
\text { depths } \\
\text { (m) }\end{array}$ & $\begin{array}{l}\text { Length } \\
\text { cored } \\
\text { (m) }\end{array}$ & $\begin{array}{l}\text { Length } \\
\text { recovered } \\
\text { (m) }\end{array}$ & $\begin{array}{l}\text { Percentage } \\
\text { recovered }\end{array}$ \\
\hline \multicolumn{8}{|c|}{ Hole $635 \mathrm{~A}$} \\
\hline 1 & $\mathbf{R}$ & 9 & 0945 & $0-2.7$ & 2.7 & 2.72 & 100 \\
\hline 2 & $\mathbf{R}$ & 9 & 1200 & $2.7-10.6$ & 7.9 & 3.30 & 41 \\
\hline 3 & $\mathbf{R}$ & 9 & 1430 & $10.6-20.1$ & 9.5 & 0.21 & 2 \\
\hline \multicolumn{8}{|l|}{ Hole 635B } \\
\hline 1 & $\mathbf{R}$ & 9 & 2230 & $0-5.6$ & 5.6 & 4.59 & 81 \\
\hline 2 & $\mathrm{R}$ & 10 & 0115 & $5.6-13.3$ & 7.7 & 2.27 & 29 \\
\hline 3 & $\mathbf{R}$ & 10 & 0335 & $13.3-22.8$ & 9.5 & 1.07 & 11 \\
\hline 4 & $\mathbf{R}$ & 10 & 0545 & $22.8-32.4$ & 9.6 & 1.50 & 15 \\
\hline 5 & $\mathbf{R}$ & 10 & 0755 & $32.4-41.7$ & 9.3 & 0.20 & 2 \\
\hline 6 & $\mathbf{R}$ & 10 & 0945 & $41.7-51.4$ & 9.7 & 0 & 0 \\
\hline 7 & $\mathbf{R}$ & 10 & 1140 & $51.4-61.0$ & 9.6 & 0.07 & 0 \\
\hline 8 & $\mathbf{R}$ & 10 & 1430 & $61.0-71.6$ & 10.6 & 2.29 & 21 \\
\hline 9 & $\mathbf{R}$ & 10 & 1730 & $70.6-80.2$ & 9.6 & 1.35 & 14 \\
\hline 10 & $\mathbf{R}$ & 10 & 2045 & $80.2-89.6$ & 9.4 & 4.08 & 43 \\
\hline 11 & $\mathbf{R}$ & 10 & 2359 & $89.6-99.1$ & 9.5 & 3.48 & 36 \\
\hline 12 & $\mathbf{R}$ & 11 & 0350 & $99.1-108.3$ & 9.2 & 3.47 & 37 \\
\hline 13 & $\mathbf{R}$ & 11 & 0800 & $108.3-113.7$ & 5.4 & 3.34 & 61 \\
\hline 14 & $\mathbf{R}$ & 12 & 0400 & $113.7-117.7$ & 4.0 & 3.44 & 86 \\
\hline \multicolumn{8}{|c|}{ Hole 636A } \\
\hline 1 & w & 12 & 1915 & $0-18.0$ & 18.0 & 0.07 & 0 \\
\hline 2 & $\mathbf{R}$ & 13 & 0123 & $18.0-21.0$ & 3.0 & 0.04 & 1 \\
\hline
\end{tabular}

${ }^{\mathrm{a}} \mathbf{R}=$ rotary; $\mathrm{W}=$ wash.

as minor proportions of grains produced on shallow carbonate banks. The layers, ranging in thickness from 10 to $35 \mathrm{~cm}$, with coarse to very coarse grains, do not display clear graded bedding. This unit, dated Pleistocene (see "Biostratigraphy" section, this chapter), is similar to Unit I of Hole $635 \mathrm{~A}$, where shallow-water carbonate grains and graded bedding are more common.

\section{Unit II (10.6/2.3-61 m sub-bottom; Core 635A-3; Cores 635B-1R-3 to 635B-7R)}

In Hole 635A, Unit II consists of a few pebbles of light gray $(2.5 Y 7 / 2)$ fine-grained limestone, locally stained yellowish brown $(2.5 Y 6 / 4)$ by limonite, of recrystallized limestone, and of finegrained, very dark grayish brown $(2.5 \mathrm{Y} 3 / 2)$ dolostone. The latter displays small burrows, features characterized by darker spots and reddish brown patches. Some of this material was dated as Late Cretaceous.

Unit II is a mixture of different lithologies in Hole 635B. These sediments have not been divided into separate units because their diversity is large and the core recovery in this part of Hole 635B is poor. The lithologic mixture of Unit II is also reflected in the ages of strata in this unit, which range from midCenomanian to mid-Pliocene without any stratigraphic order (see "Biostratigraphy" section, this chapter). At the top of Unit II, interbedded white (10YR 8/10) stiff ooze and fragmented chalk clasts (Section 635B-1R-3) of late Paleocene age are underlain by two pieces, 2 to $3 \mathrm{~cm}$ thick, of white $(5 Y \mathrm{8} / 1)$ lithified boundstone, Oligocene to Miocene in age, consisting of skeletal fragments and large foraminifers surrounded by a micritic matrix with a few small cavities partly infilled by several generations of cement (see Fig. 1). These, in turn, are underlain by a white $(2.5 Y$ 8/2) medium- to coarse-grained, massive, lithified skeletal packstone of early Campanian to late Santonian age (Sections $635 \mathrm{~B}-2 \mathrm{R}-1-50$ to $635 \mathrm{~B}-2 \mathrm{R}-42$ ).

In Core 635B-3R, early Pliocene to late Miocene light gray (5Y $7 / 10$ chalk overlies a 70 -cm-thick white $(5 Y$ 8/1) lithified floatstone. Clasts range in size from a few $\mathrm{mm}$ to $2-3 \mathrm{~cm}$ and are usually whiter than the matrix. They consist of well-indurat-

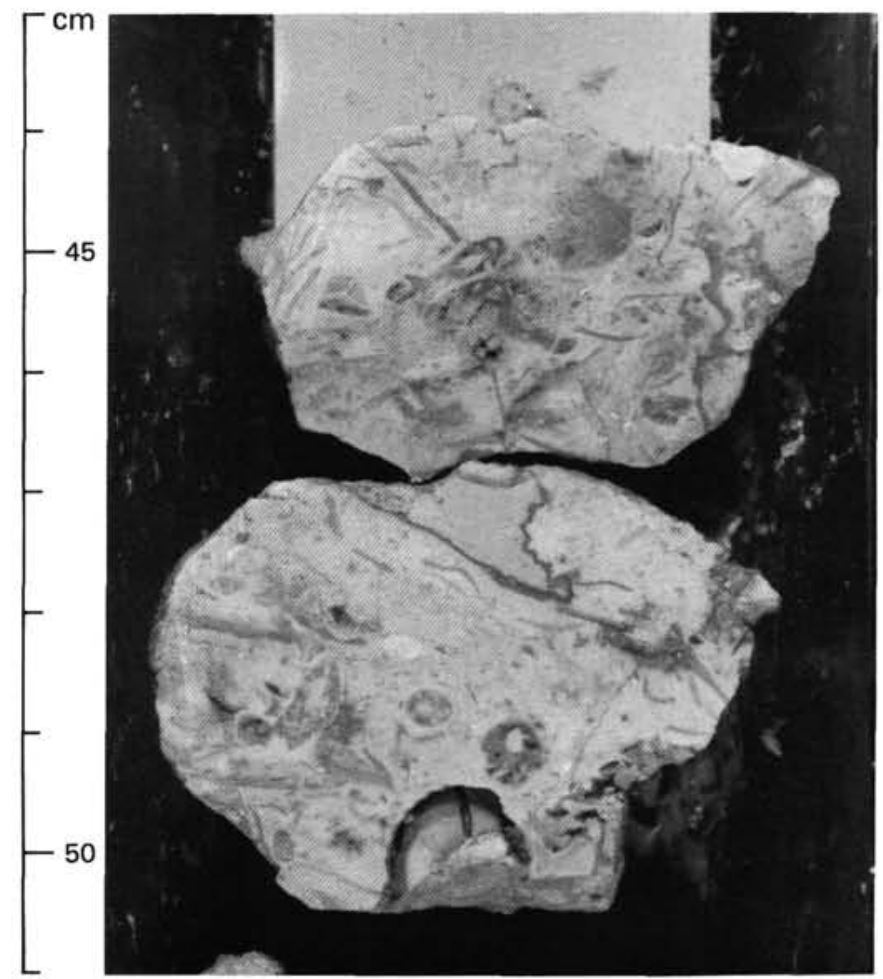

Figure 1. Lithified boundstone cobbles from Unit II, Oligocene to Miocene, consisting of skeletal fragments and large foraminifers, surrounded by a micritic matrix with a few small cavities partly infilled by several generations of cement, Sample 635B-2R-2, $44-50 \mathrm{~cm}$.

ed chalk, packstone, grainstone, rudstone, rudist shell fragments, and float in a grainy packstone matrix (see Fig. 2). Core 625B$4 \mathrm{R}$ is highly disturbed and is made up of unlithified (soupy) floatstone, rudstone, and packstone overlying an interval of light 


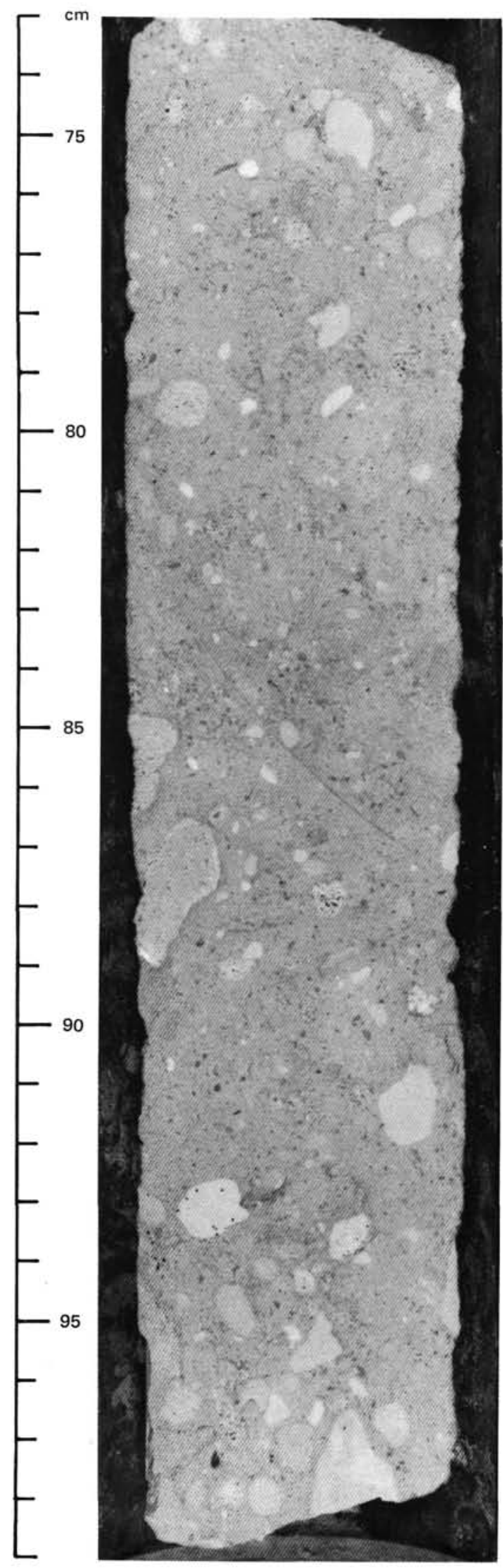

Figure 2. Lithified floatstone layer from Unit II. Clasts consist of wellindurated chalk, packstone, grainstone, rudstone, and rudist shell fragments and float in a grainy packstone matrix. Sample 635B-3R-1, 73-79 $\mathrm{cm}$. gray $(2.5 \mathrm{Y} 7 / 2)$ mid-Pliocene nannofossil ooze. Recovery in Cores $635 \mathrm{~B}-5 \mathrm{R}$ and $635 \mathrm{~B}-7 \mathrm{R}$ was poor; recovered material consists of pebbles and cobbles of lithified deep-water limestones, and shallow-water packstones, grainstones, and coral.

\section{Unit III (61-117.7 m sub-bottom; Cores 635B-8R to 635B-14R)}

Unit III is a 57-m-thick sequence characterized lithologically by a high organic content, a slight terrigenous background, and cyclic sedimentation. Unit III is divided into two subunits: Subunit IIIA (Samples 635B-8R-1 to 635B-11R-2, $40 \mathrm{~cm}$ ), interbedded dark and gray to light gray chalky limestones, and Subunit IIIB (Sample 635B-11R-2, $40 \mathrm{~cm}$, to Core 635B-14R), consisting of two thick debris flows (or slumps) separated by chalky limestone analogous to that in Subunit IIIA.

Subunit IIIA is characterized by cyclic alternation of friable and indurated dark limestone with a more massive light chalky limestone (see Fig. 3). The dark, more organic-rich limestone ranges from black (5Y 2.5/1) to gray (5Y 6/1), whereas the light limestone varies from gray to light gray $(5 \mathrm{Y} 6 / 1,7 / 1$, and $8 / 1)$. The dark limestone has a relatively lower calcium carbonate content $(85 \%-86 \%)$ than the light limestone $(91 \%-94 \%)$. The dark layers also contain some quartz and dolomite (see "Inorganic Geochemistry" section, this chapter). Both the dark and light limestones are heavily bioturbated and are only rarely laminated (see Fig. 3). Burrows are usually horizontal and range in diameter from a few millimeters to a few centimeters. In the light limestone, several generations of burrows are present, whereas in the dark limestone, burrows are fewer and smaller. In both limestones, burrows are deformed from burial compaction (see Fig. 4) but are more compacted in the dark limestones, so that in places they appear as wavy or flat laminations. Microstylolites also occur in the dark limestone. Asymmetrical microfaulting and shear structures, as well as oblique layering and folding, are present throughout this unit.

Interbedded lithified floatstone layers, a few centimeters to several tens of centimeters thick, occur throughout Subunit IIIA (Fig. 5). Their number and thickness clearly decrease toward the top of Subunit IIIA. These floatstone layers usually consist of light clasts between a few millimeters to $2-3 \mathrm{~cm}$ in size, angular or rounded, floating in a gray to light gray matrix.

Subunit IIIB consists of two major floatstones interpreted as debris-flow sequences. The upper flow (Cores 635B-11R-2, 40 $\mathrm{cm}$, to $635 \mathrm{~B}-12 \mathrm{R}, 25 \mathrm{~cm}$ ) is about $200 \mathrm{~cm}$ thick; the lower flow (Cores 635B-12R-2, $35 \mathrm{~cm}$, to 635-13R-2, $120 \mathrm{~cm}$ ) is much thicker $(420 \mathrm{~cm})$ and is capped by a $17-\mathrm{cm}$-thick turbidite. The two debris flows are separated by dark and lighter limestones displaying the same cyclic pattern as that of Subunit IIIA. The lower debris flow overlies a gray to light gray chalky limestone, which is highly bioturbated and contains burrows as large as $1-2 \mathrm{~cm}$ in diameter, and which is not as disturbed by burial as the upper part of Unit III.

The upper debris flow is a lithified floatstone consisting of light gray $(5 Y 7 / 10)$ monogenetic limestone clasts in a gray (5Y $5 / 1)$ matrix. These clasts are usually rounded and poorly sorted and some show moldic porosity. A laminated and faulted layer caused by burial deformation or downslope creep (Fig. 6) is either a large clast or a layer separating two debris flows identical in composition.

In contrast, the lower debris flow shows polygenetic round to angular clasts, ranging from a few millimeters to $10 \mathrm{~cm}$ in size and from dark gray (5Y 4/10) to light gray and white (5Y 6/1 and $5 Y 8 / 1)$. The dark, black (5Y $2.5 / 1)$ to very dark gray (5Y $3 / 1$ ), matrix shows intense deformation, contortion, and folding. Some clasts also are heavily contorted (Fig. 7). The turbidite capping this lower debris flow contains coarse, rounded gravel at its base, grading upward to medium sand and hemipelagic fine-grained limestone ( $6 \mathrm{~cm}$ thick). The top $2 \mathrm{~cm}$ shows signs of 


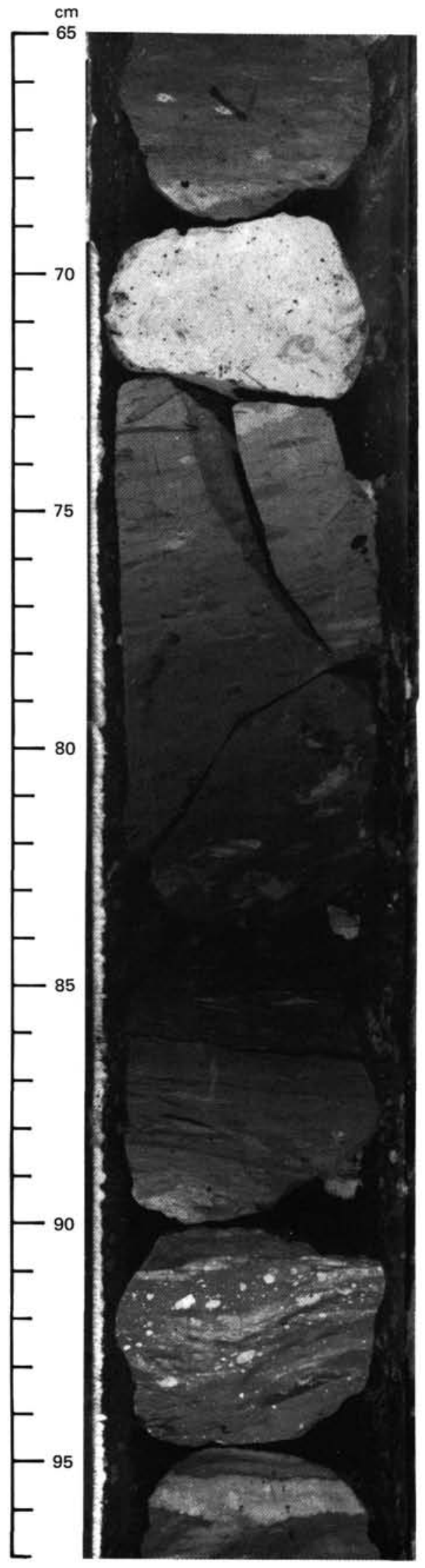

Figure 3. Cyclic alternation of a friable and indurated carbonaceous limestone with a more massive, light, chalky limestone from Subunit IIIA. Both limestones are heavily bioturbated. Sample 635B-8R-1, 65-97 cm.

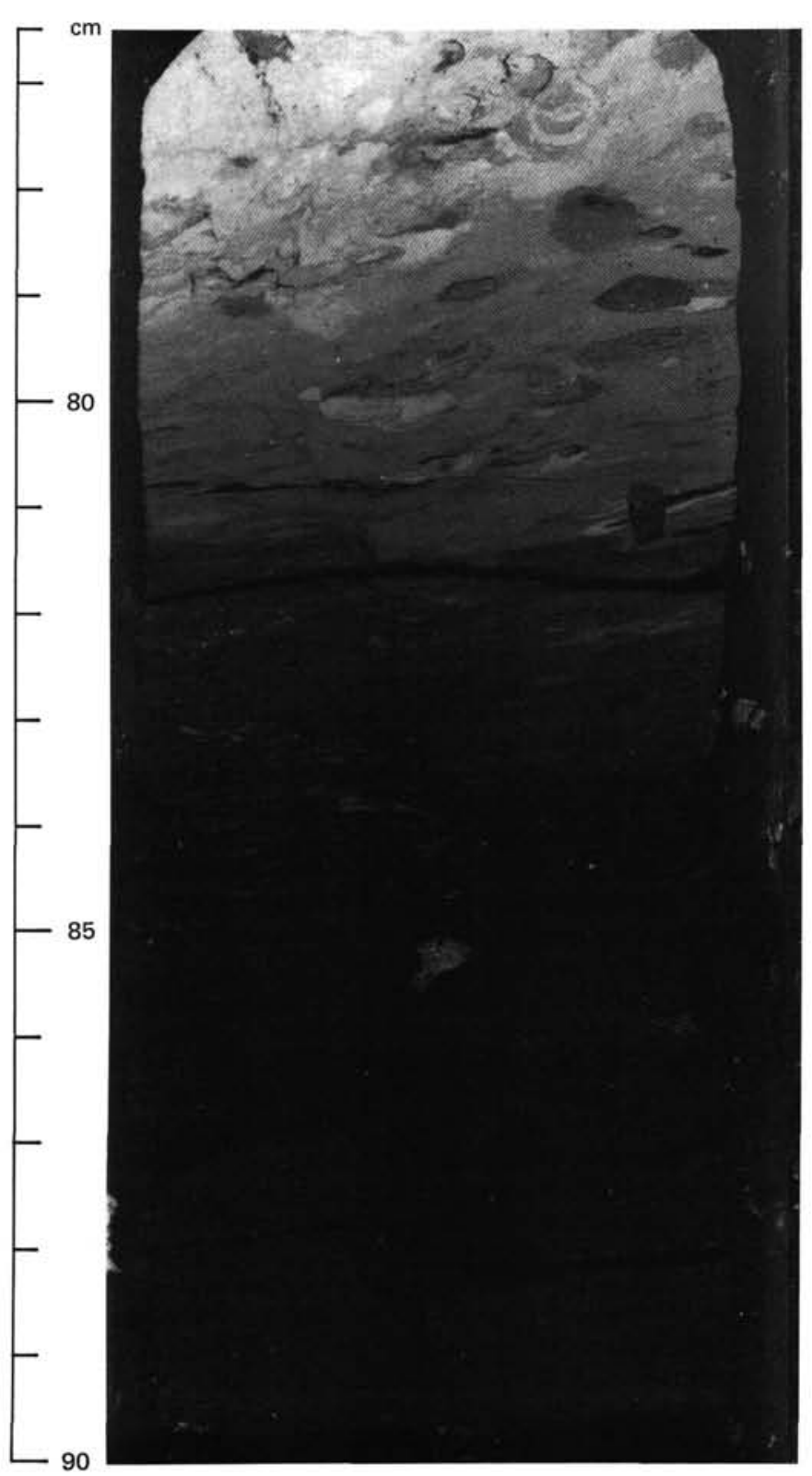

Figure 4. Burrows deformed by burial compaction in Subunit IIIA, Sample $635 \mathrm{~B}-11 \mathrm{R}-1,77-90 \mathrm{~cm}$.

bioturbation common in the pelagic limestone deposited above it (Fig. 8).

\section{Discussion}

Unit $\mathrm{I}$ is a periplatform carbonate ooze interbedded with turbidite layers. Unit II is interpreted to be either one or a series of slumps, having their origin on the steep slope of Northeast Providence Canyon and partly infilling its bottom valley. Based on its lithology and particularly on its content of benthic foraminifers (see "Biostratigraphy" section, this chapter), we interpret Unit III to have been deposited in a bathyal environment. The asymmetrical trend of the microfaulting and other deformation features, as well as the obliquity of the layering in Core 635B$10 \mathrm{R}$, slumps, and debris flows may reflect deposition on a slope. Alternatively, these features may indicate structural tilt. However, the lack of clasts derived from a carbonate-platform environment in the slumps and debris flows suggests that the slope 


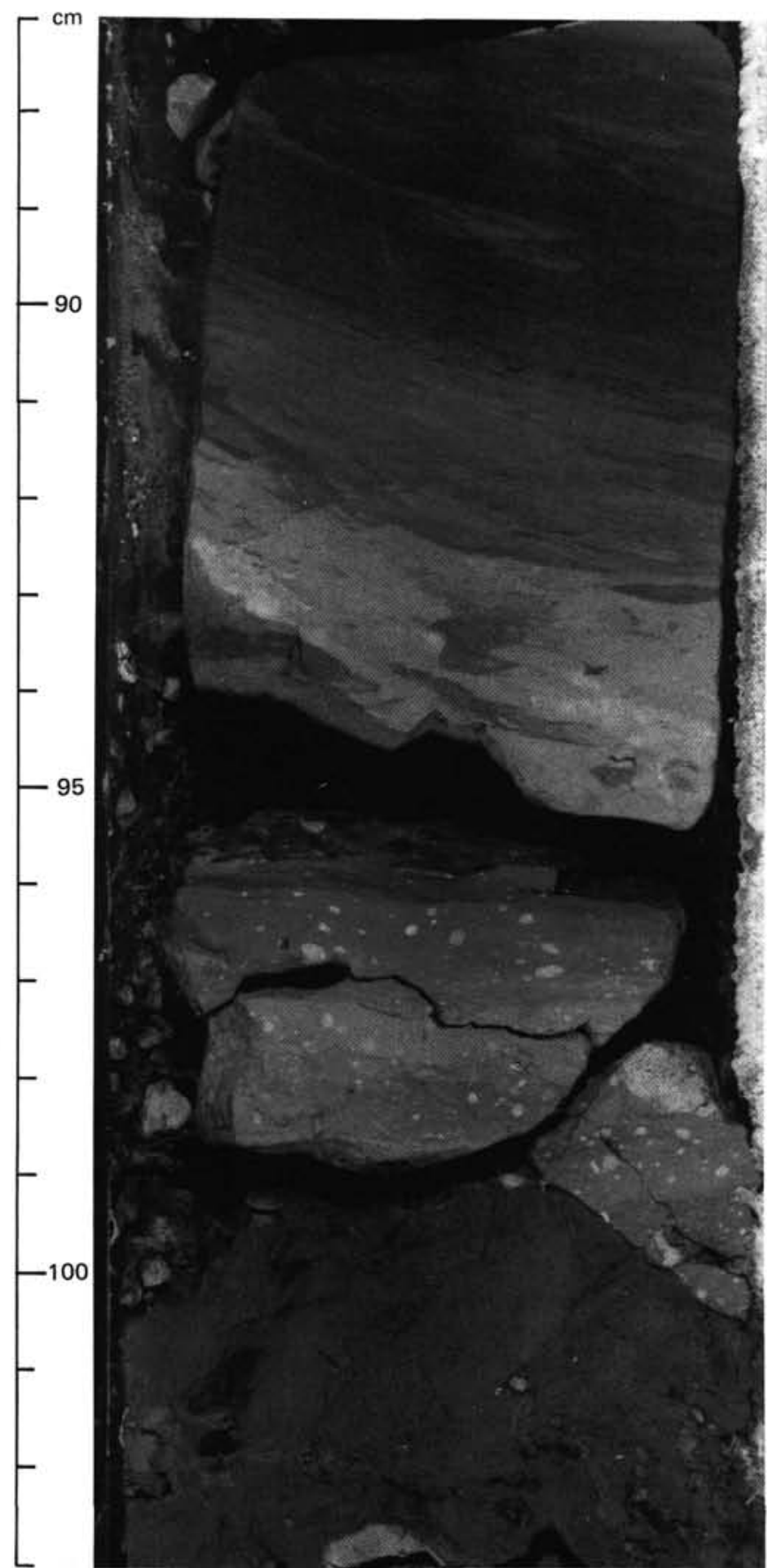

Figure 5. Lithified floatstone layers, interbedded with dark and light limestones, observed throughout Subunit IIIA. The homogeneous layer between 99 and $103 \mathrm{~cm}$ probably is drilling paste. Sample 635B-9R-1, $87-102 \mathrm{~cm}$.

was far from any platform. The gray to light chalky limestone underlying the lower debris flow may represent a different depositional environment (see "Biostratigraphy" section, this chapter).

\section{Site 636}

One hole was drilled at Site 636 , Hole $636 \mathrm{~A}$, which penetrated $21 \mathrm{~m}$ with minimal recovery $(<1 \%)$. Only two cobbles of Neogene shallow-platform limestone were obtained, one cobble from each of the two core catchers.

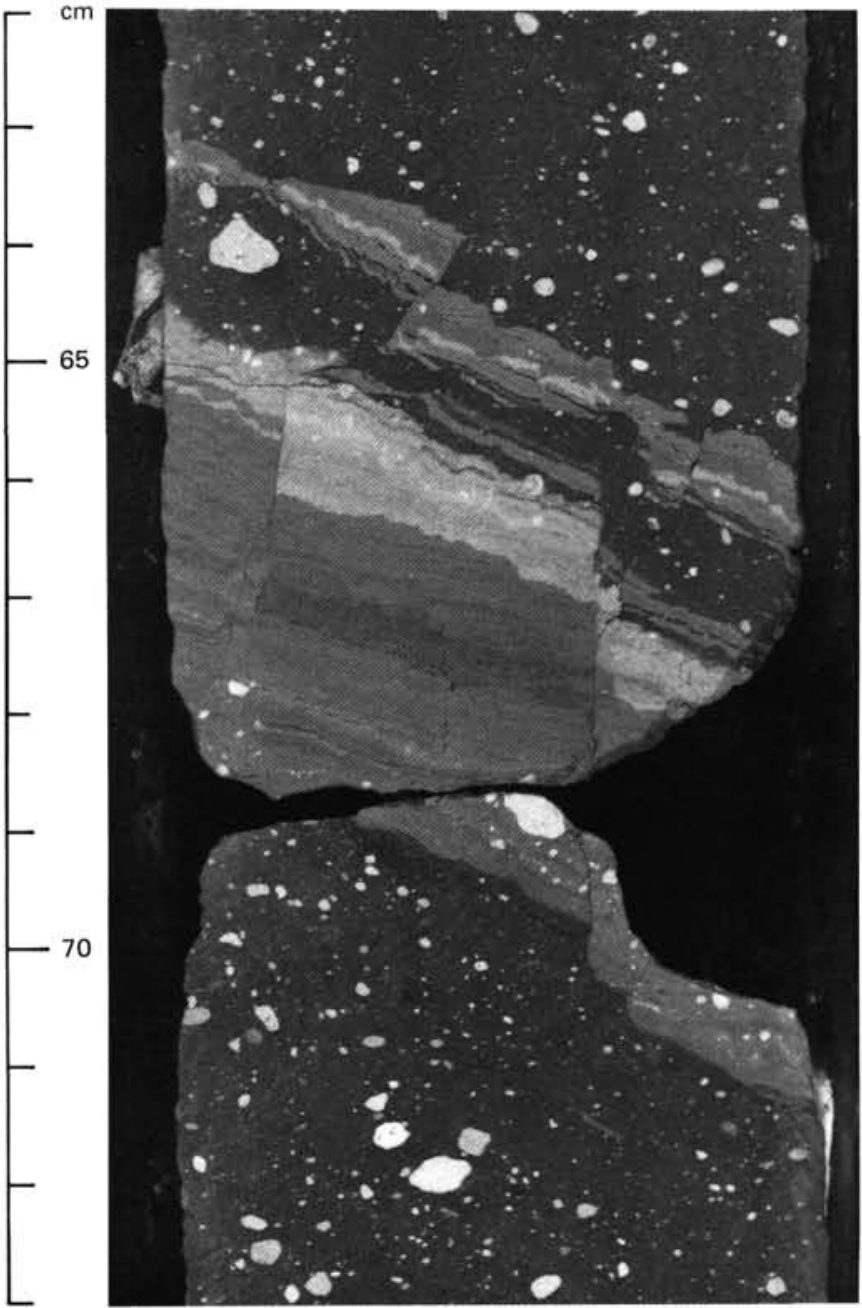

Figure 6. A laminated and faulted layer caused by burial deformation or downslope creep in a slump (Subunit IIIB). Sample 635B-11R-2, 62-73 $\mathrm{cm}$.

One cobble is a lithified grainstone, and the other a lithified rudstone. Both contain abundant skeletal fragments, including corals, bivalves, mollusks, red and green algae, and miliolid and large foraminifers. Minor interparticle and moldic porosity is filled wih calcite spar and chalk. The chalk in one cobble is $\mathrm{Pa}$ leogene in age; the chalk in the other is Neogene.

\section{Discussion}

It is clear that the cobbles were incorporated into a canyonfill deposit sometime during the Neogene. As such, they are analogous to the sediments of Unit II at Site 635.

\section{BIOSTRATIGRAPHY}

\section{Introduction}

Two holes were drilled at Site 635 . Hole $635 \mathrm{~A}$ recovered three cores of ooze, grainstone, and limestone consisting of Upper Cretaceous through Quaternary material. Hole 635B penetrated $117.7 \mathrm{~m}$ of ooze, chalk, limestone, turbidites, and debris flows. Age relationships in parts of this hole are uncertain owing to the chaotic nature of the sequence, which is probably a slump or slumps (see "Sedimentology" section, this chapter) with largescale incorporation of older sediments of highly variable age. It 


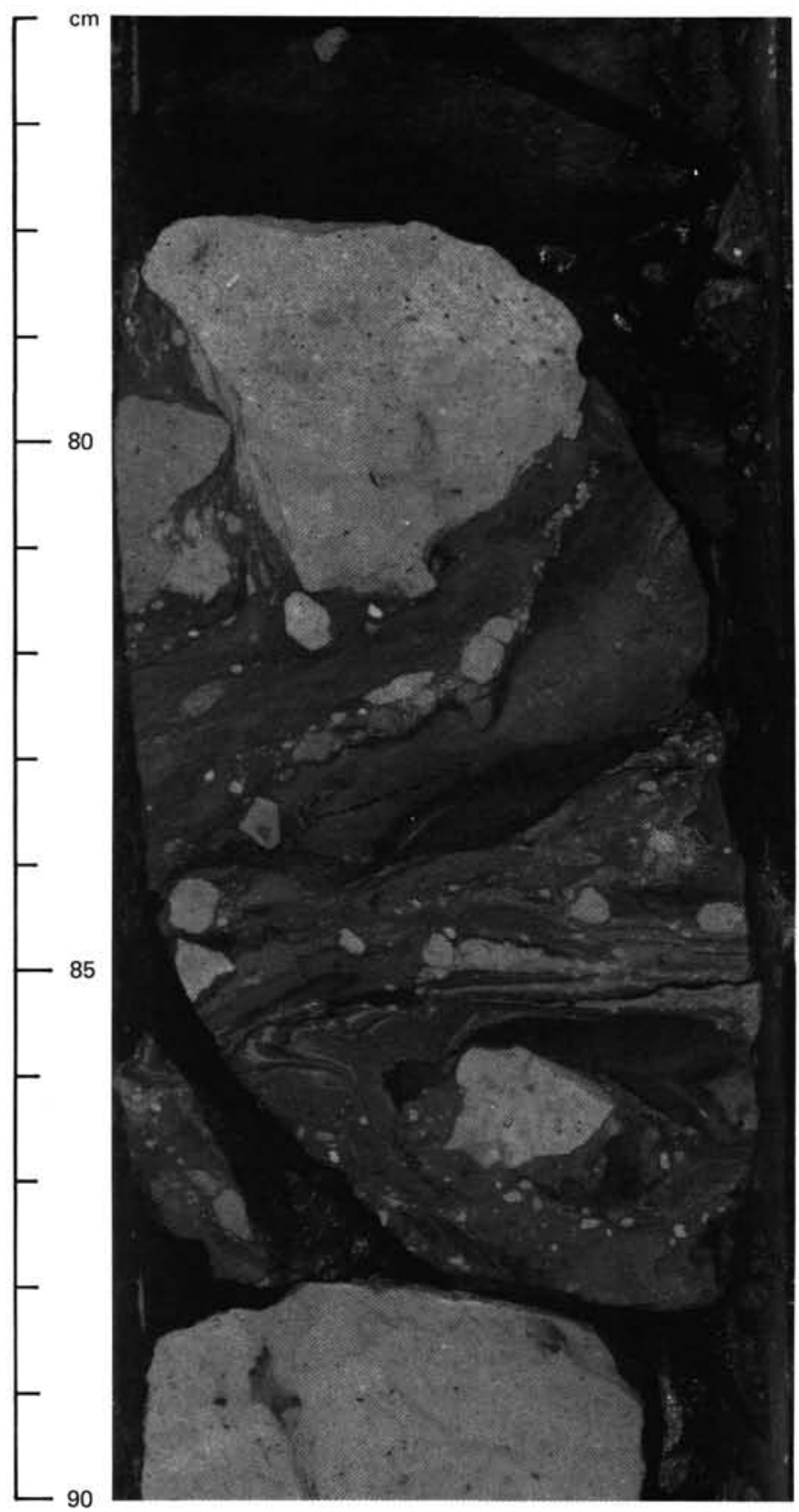

Figure 7. Heavily contorted clasts in the major slump of Subunit IIIB, Sample 635B-13R-2, 76-90 cm.

is, in fact, rather difficult to determine the timing of the emplacement of the slump(s) penetrated by the upper seven cores of Hole 635B. The interval from Cores 635B-8R through 635B-14R appears to exhibit normal sedimentary relationships, with age increasing regularly with depth. Well-developed and relatively thick debris flows in this interval indicate, however, that caution must be applied in drawing conclusions based on age relationships. Whenever possible, an effort has been made to sample perennial sediment as opposed to obviously displaced material.

\section{Calcareous Nannofossils}

\section{Hole 635A}

Core $635 \mathrm{~A}-1 \mathrm{R}$ contains assemblages with abundant Emiliania huxleyi, indicating the E. huxleyi Acme Zone (of Gartner, $\mathrm{cm}$

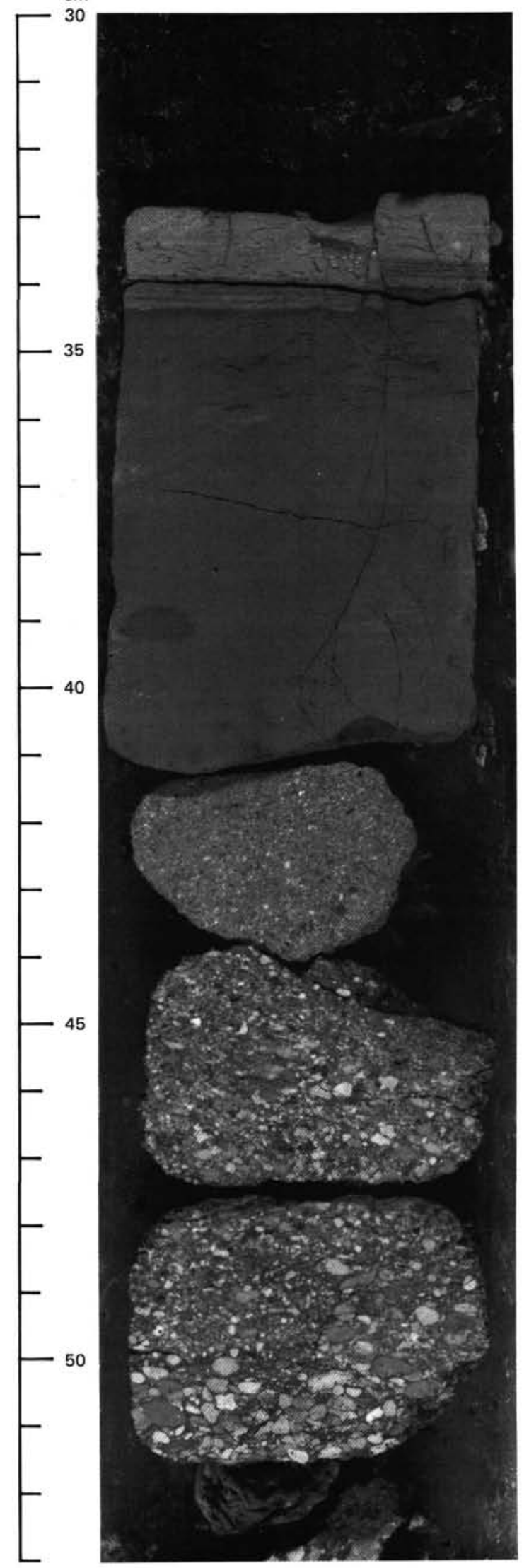

Figure 8. Turbidite layer capping the major slump of Subunit IIIB. Notice that bioturbation is restricted to the very top of the turbidite. Sample $635 \mathrm{~B}-12 \mathrm{R}-2,30-53 \mathrm{~cm}$. 
1977), which correlates with the latest Pleistocene and Holocene. Core 635A-2R contains Pseudoemiliania lacunosa, Gephyrocapsa oceanica, and Gephyrocapsa caribbeanica. This assemblage is assigned to Zone NN19, which correlates with the early to middle Pleistocene. Core $635 \mathrm{~A}-3 \mathrm{R}$ contains only well-lithified carbonates that did not yield any nannofossil assemblages. A sample taken from softer mud adhering to the core catcher contains a poorly preserved assemblage including numerous Late Cretaceous forms, although assignment of this assemblage to a specific stage is not possible based only on this sample.

\section{Hole 635B}

Sample 635B-1R-1, 0-1 cm, contains fossils of the E. huxleyi Acme Zone, which is correlated with the latest Pleistocene to Holocene. This Quaternary material lies atop white chalk of late Paleocene Zone NP8. This zonal assignment is based on the presence of characteristic Paleocene forms including Fasciculithus tympaniformis, Sphenolithus primus, and Discoaster nobilis in the absence of Discoaster multiradiatus. Sample 635B-2R-1, 141-143 cm, contains a Santonian-?Campanian assemblage that includes Lithastrinus septenarius, Eiffellithus eximius, Micula decussata, Lucianorhabdus maleformis, and Quadrum gartneri (late forms). This sample appears to be part of a debris flow. Samples of a lithified packstone matrix from Section 635B-2R-2 contain a mixed Oligocene-Neogene assemblage exhibiting good preservation. The stratigraphic integrity of this material is still uncertain.

Core 635B-3R contains a number of different lithologies of varying ages. Sample 635B-3R-1, 4-5 cm, contains a Cenomanian assemblage with Eiffellithus turrisseiffeli, Corollithion protosignum, Corollithion kennedyi, and Rhagodiscus asper. This material appears to be part of a turbidite. This Cenomanian material is underlain by approximately $5 \mathrm{~cm}$ of gray chalk containing early Pliocene (NN14/15) nannofossils. Below this Pliocene chalk is a debris flow containing clasts of varying lithologies including shallow-water-platform material.

Section 635B-4R, CC contains an abundant, well-preserved assemblage including Discoaster asymmetricus, Discoaster surculus, Reticulofenestra pseudoumbilica, and Sphenolithus abies, indicating Zone NN15, which correlates with the late early Pliocene. This material appears to be in-situ, perennial sediment. If this assumption is correct, it constrains the emplacement of the overlying debris-flow material to be no older than mid-Pliocene.

Cores $635 \mathrm{~B}-5 \mathrm{R}$ through $635 \mathrm{~B}-7 \mathrm{R}$ did not recover any sediment that can be dated by calcareous nannofossils.

The interval from Cores 635B-8R through 635B-14R consists of a mixture of debris flows, turbidites, and marly limestones. At present, the age assignments for the sediment gravity-flow deposits have not been undertaken in detail. Finely laminated and/or burrow-mottled marly limestones that appear to be perennial sediment have been preferentially sampled in an effort to establish the timing of sediment gravity-flow emplacement. Based on rather limited evidence, however, it would appear that little difference in age exists between the "perennial" sediment and much of the sediment gravity-flow matrix, suggesting penecontemporaneous sediment mobilization and emplacement of the sediment gravity flows. Further work will be necessary to test this hypothesis.

The interval from Core 635B-8R through Sample 635B-12-1R, $110 \mathrm{~cm}$, contains assemblages that include Eiffellithus turrisseiffeli, Tranolithus orionatus, Rhagodiscus asper, and Reinhardtites fenestratus but lack Hayesites albiensis and Lithraphidites acutum. This assemblage indicates the Prediscosphaera spinosa Subzone of the $E$. turrisseiffeli Zone, which is correlated with the latest Albian through the middle Cenomanian. The eiffellithids in the upper part of this sequence suggest the younger part of the zone. Downsection through this interval the eiffellithids become progressively more primitive, indicating the early $\mathrm{Ce}$ nomanian or latest Albian (Sample 635B-12-1R, $110 \mathrm{~cm}$ ). In addition, the occurrence of Braarudosphaera africana and Braarudosphaera hockwoldensis in Sample 635B-12-1R, $110 \mathrm{~cm}$, indicates the earliest Cenomanian or latest Albian. The occurrence of this assemblage with the addition of Hayesites albiensis in Section 635B-12R, CC indicates the late Albian H. albiensis Subzone of the E. turrisseiffeli Zone.

Sample 635B-13-2R, 75-77 cm, through Section 635B-14R, CC (total depth) contains Prediscosphaera columnata, Tranolithus orionatus, and Hayesites albiensis without Eiffellithus turrisseiffeli, indicating the Prediscosphaera columnata Zone. This zone is correlated with the late early through early late Albian. The presence of Tranolithus orionatus further constrains the age of this interval to the early late Albian. This age is significant in that it is definitely older than the green marls that overlie the platform top at Site 627. This suggests two possibilities: either there is a significantly longer hiatus between the green marls and the platform top at Site 627 than was previously suspected, or the platform drowning was diachronous. Based on available evidence, however, diachronous platform drowning appears to be the more likely hypothesis.

The nature of the nannofossil assemblages in this interval also suggests paleoenvironmental change. Samples from Sections 635B-13-2, 635B-14-3, and 635B-14, CC contain abnormally high abundances of Nannoconus spp., Braarudosphaera spp., and Corollithion spp. as compared to the overlying Albian assemblages. Various authors have used high abundances of one or more of these genera as an indicator of shallow oceanic conditions. These relationships suggest decreasing water depth downhole through this upper Albian sequence.

\section{Planktonic Foraminifers}

\section{Hole 635A}

Core-catcher samples from Cores 635A-1R and 635A-2R (10.6 m sub-bottom) contain planktonic foraminifers of the Globorotalia truncatulinoides Zone. Core $635 \mathrm{~A}-1 \mathrm{R}$ is late Pleistocene in age (N23), whereas Core 635A-2R is early to mid-Pleistocene $(\mathrm{N} 22 / \mathrm{N} 23)$ on the basis of co-occurrence of Globorotalia truncatulinoides and $G$. tosaensis. Both intervals also contain reworked early Pliocene planktonic foraminifers.

\section{Hole 635B}

Cores 635B-1R through 635B-4R (32.4 m sub-bottom) contain a wide variety of lithologies and ages that probably represent canyon fill since the mid-Pliocene. The upper part of Core $635 \mathrm{~B}-1 \mathrm{R}$ is an ooze of late to mid-Pleistocene age (N22/N23). Section 635B-1R-3 consists of white pelagic ooze-chalk, assigned a late Paleocene age (Planorotalites pseudomenardii Zone, P4). Diagnostic taxa include Morozovella velascoensis, $M$. occlusa, $M$. angulata, Planorotalites pseudomenardii, and $P$. chapmani. Section 635B-1R-4 contains both the Paleocene ooze and Pleistocene ooze, but core-catcher failure on the drill floor resulted in a "hand-packed" mixture of the two lithologies.

Loosely consolidated Pleistocene debris is found in the upper part of Section 635B-2R-1. The lower part of Section 635B-2R-1 and the upper half of Section 635B-2R-2 contain grainstones of latest Santonian-early Campanian age (Globotruncana elevata Zone). The grainstones resemble similar lithologies recovered at Site 634.

Planktonic foraminifers ranging in age from middle Cenomanian to middle Turonian are present in lithified chalk in the lower half of Section 635B-2R-2 and the upper $10 \mathrm{~cm}$ of Section 635B3R-1. Diagnostic taxa include Rotalipora reicheli, $R$. greenhornensis, $R$. cushmani, Praeglobotruncana stephani, Globotrunca- 
na helvetica, and G. sigali. A gray chalk in Sample 635B-3R-1, $11-14 \mathrm{~cm}$, is latest Miocene-early Pliocene in age. The remainder of Core 635B-3R consists of a lithified debris flow whose matrix resembles the chalk in the upper part of Section 635B3R-1. An early Turonian age is suggested for Sample 635B-3R-1, 58-60 $\mathrm{cm}$, based on the presence of Globotruncana helvetica and $G$. hagni.

A brownish gray ooze in Section 635B-4R, CC yields an early late Pliocene age (Globorotalia miocenica Zone). Poor core recovery and insufficient soft material in Cores 635B-5R through 635B-7R preclude shipboard age determination.

Marly chalks and marly limestones are present in Cores 635B-8R to $635 \mathrm{~B}-14 \mathrm{R}$ (61.0-117.7 $\mathrm{m}$ sub-bottom). Slumps and debris flows occur throughout much of this interval. A latest Albian age (Vraconian), corresponding to the Planomalina buxtorfi Zone, is suggested for Cores 635B-8R to 635B-13R-2 (106.5 $\mathrm{m}$ sub-bottom). Diverse, open-ocean assemblages of planktonic foraminifers occur throughout this interval. Diagnostic taxa include Planomalina buxtorfi, Rotalipora appenninica, Rotalipo$r a$ sp. cf. $R$. gandolfii, Hedbergella libyca, Praeglobotruncana delrioensis, and Globigerinelloides bentonensis. Biticinella breggiensis occurs in the base of Core 635B-12R and in Cores 635B$13 \mathrm{R}$ and $635 \mathrm{~B}-14 \mathrm{R}$, and therefore indicates an age no younger than early Vraconian for this latter interval.

A major change in the planktonic-foraminiferal assemblages occurs near a suspected stratigraphic break in Sample 635A13R-2, $120 \mathrm{~cm}$. Keeled species are absent in Cores 635B-13R, $\mathrm{CC}$ and 635B-14R. The occurrence of Biticinella breggiensis, Ticinella roberti, and $T$. primula suggests an early late Albian age (Biticinella breggiensis Zone) for this interval. However, an early Vraconian age (Planomalina buxtorfi Zone) cannot be ruled out on the basis of planktonic-foraminiferal evidence. The absence of keeled taxa of planktonic foraminifers may be a function of environmental exclusion and may reflect a shoaling paleoenvironment similar to the Cenomanian marly-chalk sequence overlying the drowned carbonate platform at Site 627.

\section{Larger Foraminifers}

\section{Hole 635A}

Archaias angulatus and Amphistegina sp. occur in Samples 635A-1R, CC, 635A-1R-2, 92-95 cm (late Pleistocene), and 635A2R, CC (middle Pleistocene).

\section{Hole 635B}

Sample 635B-3R-1, 1-3 cm, yields miliolids and Cuneolina sp. from the Cretaceous. A thin-section of (?Pliocene) platform limestone from Sample 635B-3R-2, 43-46 cm, contains Archaias angulatus, Sphaerogypsina sp., and Amphistegina sp. The sieved fraction of Sample 635B-4R-1, 22-24 cm, contains Archaias angulatus, Amphistegina sp., and calcareous algae. This sample has been dated as mid-Pliocene on the basis of planktonic microfossils. Thin sections of platform limestone from Samples 635B-4R-1, 43-44 cm, and 635B-4R-1, 90-100 cm, contain Archaias angulatus, Amphistegina sp., and miliolids.

Except for Cuneolina sp., the species of larger foraminifers found at this site are shallow-water-platform dwellers. These forms are known from Oligocene to Holocene sediments. Those occurring as isolated specimens in Sample 635B-4R-1, 22-24 cm, can be considered to have been redeposited by turbidites. Specimens occurring in lithified pieces of platform limestone have been reworked from shallow water by sediment gravity flow.

\section{Hole 636A}

Thin sections made from the sole piece of grainstone-boundstone recovered in Section 636A-1R, CC contain the calcareous algae Dermatholithion sp. and Lithoporella sp. and the large foraminifers Amphistegina sp. and Sorites sp. or Miosorites sp. Section 636A-2R, CC contains Sphaerogypsina sp., Archaias angulatus, and Sorites $\mathrm{sp}$. or Miosorites $\mathrm{sp}$. The latter two genera are known from Miocene to Holocene sediments. The two pieces of Neogene limestone (636A-1R, CC and 636A-2R, CC) come from the Bahama Platform and are reworked by gravity flow into the deep basin of Northeast Providence Channel.

\section{SEDIMENT-ACCUMULATION RATES}

Cores $635 \mathrm{~B}-7 \mathrm{R}$ to $635 \mathrm{~B}-1 \mathrm{R}$ recovered a diverse mixture of lithologies ranging in age from mid-Cretaceous to Holocene (Fig. 9). Based on biostratigraphy, this sequence probably represents episodic canyon fill since the mid-Pliocene. Cores $635-14 \mathrm{R}$ to 635B-8R contain a section of upper Albian carbonaceous chalks. Debris flows and slumps characterize much of this lower sequence, which accumulated at a rate of about $35-36 \mathrm{~m} / \mathrm{m}$.y.

\section{INORGANIC GEOCHEMISTRY}

\section{Interstitial Waters}

One water sample was taken from Hole 635A. This sample (see Table 2), from $2.4 \mathrm{~m}$ sub-bottom, has a composition similar to bottom seawater.

\section{X-Ray Studies}

Sediments from Holes 635A and 635B (see Fig. 10 and Table 3) are composed principally of low-Mg calcite. In the Pliocene and Pleistocene portions of the holes, however, aragonite and high- $\mathrm{Mg}$ calcite persist to depths of $22.93 \mathrm{~m}$ sub-bottom. The persistence of these minerals agrees with the interpretation of this unit as a slump (see "Sedimentology" section, this chapter).

The Cretaceous portion of Hole 635B is dominated by low$\mathrm{Mg}$ calcite and has an acid-soluble (carbonate) fraction of greater than $85 \%$ (see "Sedimentology" section, this chapter). These residues are composed of quartz, pyrite, microcline, and various clay minerals (smectite, chlorite, and palygorskite). No consistent differences in the percentages of quartz, dolomite, calcite, or any other trace constituent were observed between the lighter and darker units of Cenomanian sediments. The failure to detect a difference implies that the color changes are the result of variations in organic content. Overall, the proportions of these minerals are very small compared to the Cenomanian marls described at Site 627.

The clay-mineral assemblage at Site 635 is dominated by smectites. This contrasts to previous sites in which smectite was absent or a minor component. This difference is interpretable as indicating an influence from the alteration of ultramafic rather than felsic materials.

\section{Carbonate-Bomb Data}

Only a few samples were available for carbonate-bomb determinations from Site 635 (Fig. 11 and Table 4). These samples yielded high values of $93 \%-97 \% \mathrm{CaCO}_{3}$ in the upper $20 \mathrm{~m}$, and lower values $(81 \%-86 \%)$ from 20 to $80 \mathrm{~m}$ sub-bottom. Slightly higher carbonate contents $(88 \%-94 \%)$ were recorded below $80 \mathrm{~m}$ sub-bottom.

\section{ORGANIC GEOCHEMISTRY}

Seventeen samples were taken from Hole 635B for Rock-Eval analysis. In addition, several gas samples were taken.

The gross lithology at Hole 635B consists essentially of an upper section of slumped rocks of various ages (Cretaceous to Quaternary, 0-61 m sub-bottom) and a lower section of in-situ Albian-Cenomanian carbonaceous limestones (61-118 m sub- 


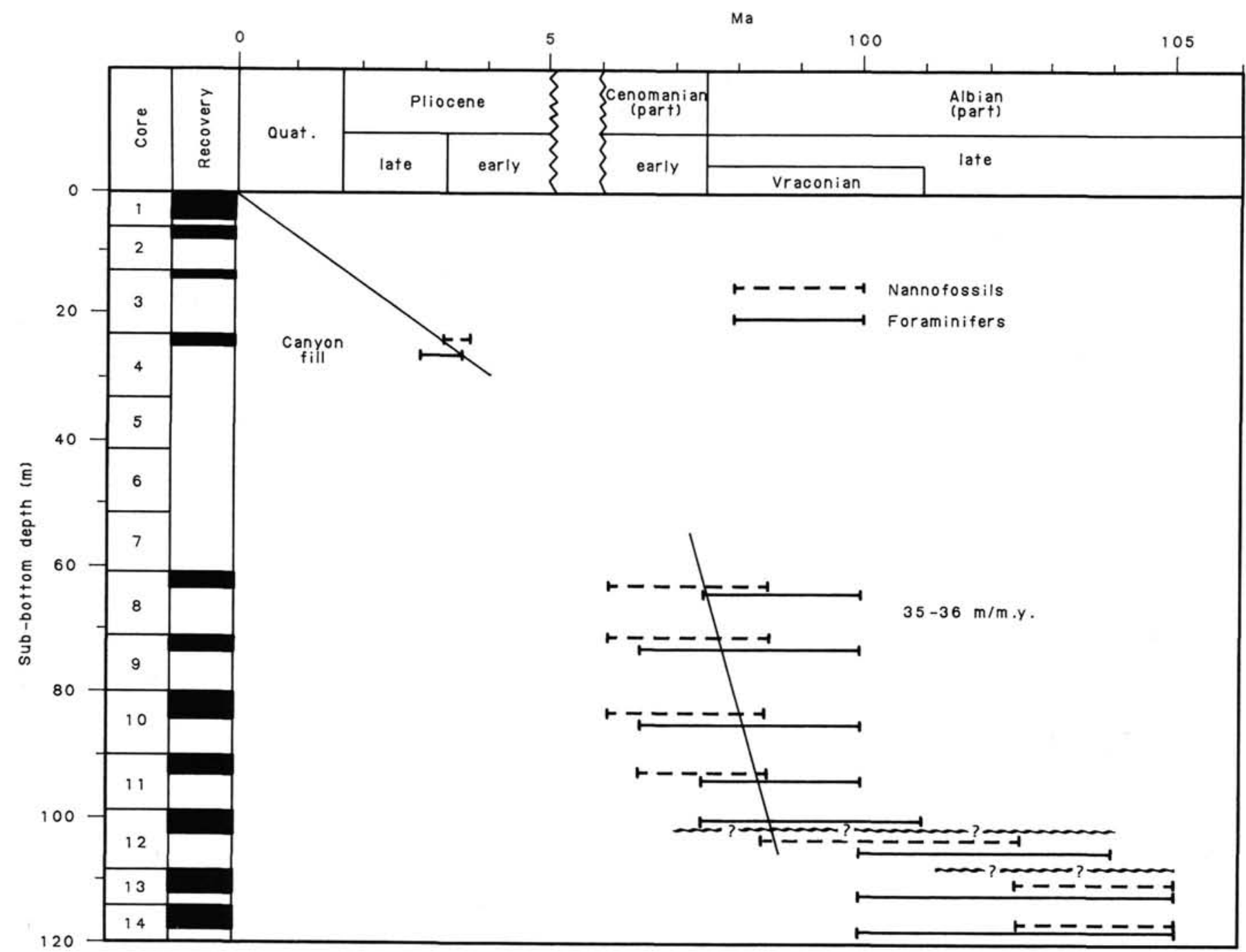

Figure 9. Sediment-accumulation rates, Site 635.

Table 2. Analyses of interstitial waters from Hole 635A.

\begin{tabular}{cccccccc}
\hline $\begin{array}{c}\text { Sub-bottom } \\
\text { depth } \\
(\mathrm{m})\end{array}$ & $\mathrm{pH}$ & $\begin{array}{c}\text { Alkalinity } \\
(\mathrm{meq} / \mathrm{kg})\end{array}$ & $\begin{array}{c}\text { Salinity } \\
(\% \circ)\end{array}$ & $\begin{array}{c}\text { Chlorinity } \\
(\% 0)\end{array}$ & $\begin{array}{c}\mathrm{Ca} \\
(\mathrm{mmol} / \mathrm{L})\end{array}$ & $\begin{array}{c}\mathrm{Mg} \\
(\mathrm{mmol} / \mathrm{L})\end{array}$ & $\begin{array}{c}\mathrm{SO}_{4} \\
(\mathrm{mmol} / \mathrm{L})\end{array}$ \\
\hline $\begin{array}{c}\text { Surface seawater } \\
2.4\end{array}$ & 8.07 & 2.384 & 36.2 & 20.33 & 10.81 & 55.83 & - \\
\hline
\end{tabular}

bottom; see "Sedimentology" section, this chapter, for a detailed description of the stratigraphy). The term carbonaceous is used here to define lithified sediments with total-organic-carbon (TOC) values of $2 \%$ or more.

Only one sample was taken from the upper section. It contained tiny amounts of $\mathrm{S}_{2}$, i.e., pyrolysable hydrocarbon (see Fig. 12), and negligible amounts of hydrocarbon ( $S_{1}$; see Fig. 13). This sample also yielded an overmature value for $T_{\max }\left(460^{\circ} \mathrm{C}\right)-$ i.e., it contained organic matter that had undergone prolonged heating (mainly detrital, reworked organic carbon). Visually, the rest of the upper section appeared to be very low in organic content.

The lower section, lithologic Unit III, was strikingly different. The $\mathrm{S}_{2}$ content of the carbonaceous limestones was high, usually more than 2 , indicating good oil source rocks. In five samples, extremely high values were noted (11.5-15.5). Visually, the higher the $\mathrm{S}_{2}$ content, the more intensely black the sediment appeared.

The $\mathrm{S}_{2} / \mathrm{S}_{3}$ ratio (Fig. 14) showed a greater scatter of values, ranging from 0.25 to 2.5 (gas prone, probably terrestrially derived kerogen, 10 samples), mixed gas- and oil-prone kerogen ( $\mathrm{S}_{2} / \mathrm{S}_{3}$ values between 2.5 to 5,5 samples), and oil-prone algal kerogen $\left(\mathrm{S}_{2} / \mathrm{S}_{3}>5.0,3\right.$ samples). These values indicate kerogen types III/IV, III/II, and II/I, respectively. TOC values were not available for more precise evaluation of kerogen type.

The $S_{1}$ content of the carbonaceous limestones was minor, being always less than 0.5 , indicating immature kerogen not capable of acting as an oil source.

$\mathrm{T}_{\max }$ values derived from the analyses indicate immaturity, being approximately $420^{\circ} \mathrm{C}$ (oil generation is associated with $T_{\max }$ 


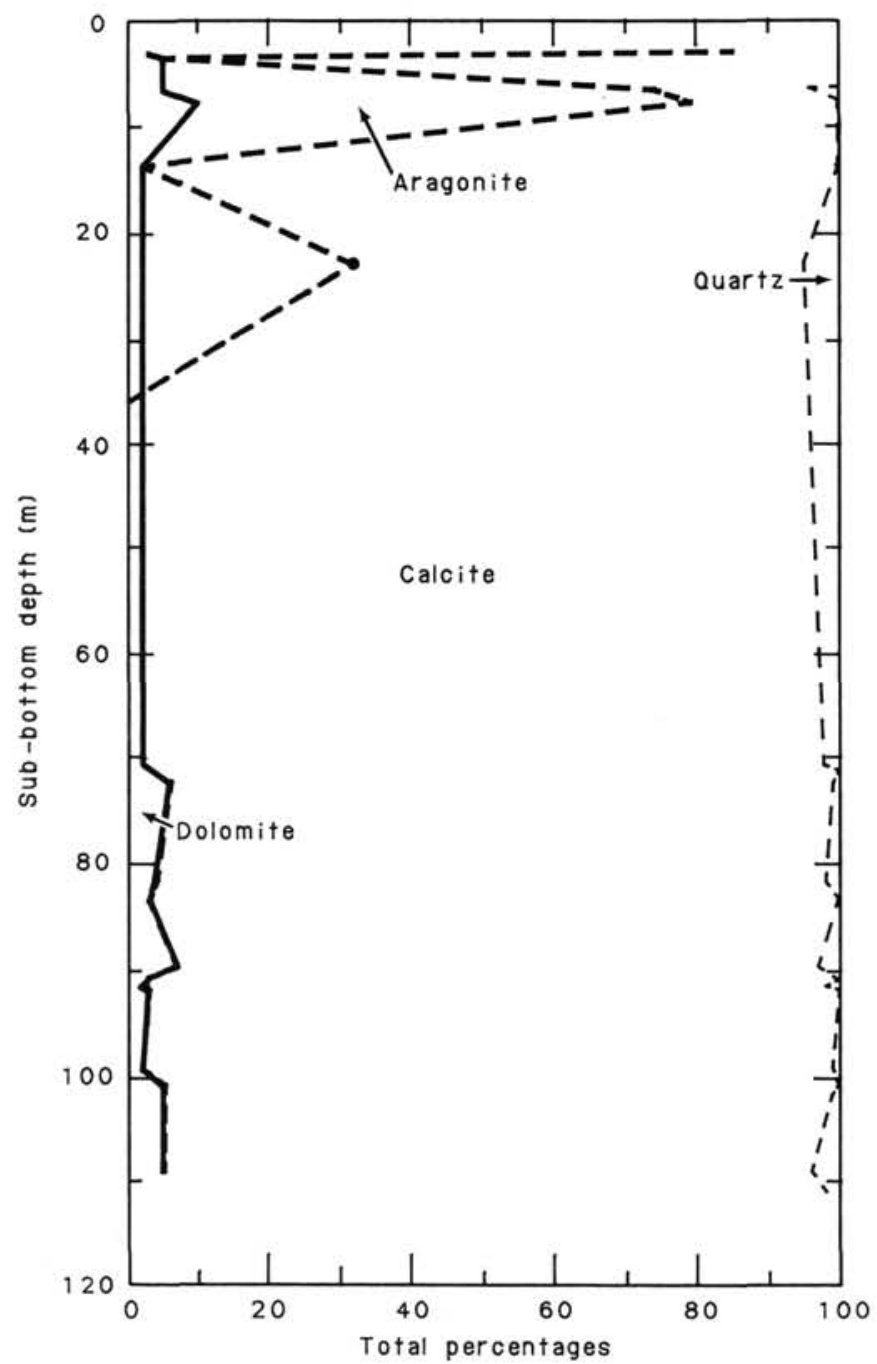

Figure 10. X-ray data, Site 635.

values of $\left.435^{\circ} \mathrm{C}\right)$. These values are similar to those of the Cenomanian green marly chalks and chalks of Site 627 .

\section{Gas Data}

Little gas was contained in the core sections investigated. The concentrations were at blank levels.

\section{Discussion}

It appears that a major organic-facies distinction exists between the back-reef evaporite (gypsum) deposits at Site 627 and the deep-water carbonaceous limestones at Site 635, although both are good potential source rocks of Albian age. The gypsum contains type I kerogen (marine), whereas the carbonaceous limestone contains types II/III kerogens (mixed marine-terrestrial). Both depositional environments of accumulation may have involved stratified marine anoxic water columns.

\section{PALEOMAGNETISM}

\section{Natural Remanent Magnetization}

No oriented paleomagnetic samples were collected from Hole $635 \mathrm{~A}$, because the few cores recovered consisted mainly of unconsolidated sand that did not seem promising as a magneticfield recorder. However, 21 oriented $12-\mathrm{cm}^{3}$ minicores were obtained from middle Cretaceous sediments in Hole 635B. All of these samples were too weakly magnetized to be accurately mea- sured with the shipboard Molspin spinner magnetometer, the largest magnetization being about $3 \times 10^{-6} \mathrm{emu}$.

\section{Magnetic Susceptibility}

Fifty-nine whole-core magnetic-susceptibility measurements were made of cores recovered from Hole 635A, whereas 223 such measurements were made of Hole 635B cores. The raw susceptibility values from each hole, plotted vs. depth, are shown in Figure $15 \mathrm{~A}$. In Hole 635A the susceptibility was high and variable apparently because of rust contamination. Rust flakes were noted in both Cores 635A-1R and 635A-2R.

The susceptibility values recorded from Hole $635 \mathrm{~B}$ cores were higher in general than those measured from cores taken from other Leg 101 holes. The susceptibility appears to increase slightly with depth. The average susceptibility for Core 635B-2R, at $5.6 \mathrm{~m}$ sub-bottom, is $0.5 \times 10^{-6} \mathrm{G} / \mathrm{Oe}$. Near the bottom of the hole the average value for Core 635B-13R, at $108.3 \mathrm{~m}$ sub-bottom, is $1.1 \times 10^{-6} \mathrm{G} / \mathrm{Oe}$. Although these values are representative of most Hole 635B measurements, Figure 15B shows considerable variation in susceptibility within each of the individual cores. The one large susceptibility spike is caused by rust contamination; however, some of the smaller spikes appear to reflect the actual variation in susceptibility among sediments of slightly differing composition.

A general correspondence between color and susceptibility was noted. The lighter colored sediments, presumably containing a larger fraction of calcium carbonate, had lower susceptibilities than their darker counterparts. For example, the average susceptibility value in the upper $90 \mathrm{~cm}$ of Core $635 \mathrm{~B}-8 \mathrm{R}$ is about $0.4 \times 10^{-6} \mathrm{G} / \mathrm{Oe}$, but the average in the $60 \mathrm{~cm}$ below that jumps to $2.8 \times 10^{-6} \mathrm{G} / \mathrm{Oe}$. This change roughly coincides with a change in the color of the sediment from light to dark gray. As a search for rust flakes within this section found none, the change is evidently not a result of metallic contamination of the core. Similar contrasts, though not as large, were noted in Cores 635B-9R and 635B-10R.

\section{PHYSICAL PROPERTIES}

Physical-property measurements were made on sediment recovered from Site 635 as described in the "Introduction and Explanatory Notes" chapter (this volume). Hole 635A cored only $20.1 \mathrm{~m}$ sub-bottom before the hole was abandoned. Data from Hole 635A are recorded in Table 5. Hole 635B was cored between the water/sediment interface to $117.7 \mathrm{~m}$ sub-bottom, and results are recorded graphically in Figure 16 and Table 5.

\section{Compressional Wave Velocity}

Compressional wave velocity signals through the mud, sand, and ooze recovered in the upper $3.7 \mathrm{~m}$ sub-bottom of Hole 635B were weak. Below $3.7 \mathrm{~m}$ sub-bottom, sediment was indurated, and discrete samples were removed from the core liner and strong compressional wave velocity signals measured. The velocity measured was highly dependent on the lithology sampled. Between 3.7 and $32.4 \mathrm{~m}$ sub-bottom, velocity values average $3450 \mathrm{~m} / \mathrm{s}$, with grainstones being the predominant lithology. At $51 \mathrm{~m}$ subbottom, velocities of $5000 \mathrm{~m} / \mathrm{s}$ were measured from limestone cobbles. Between 61 and $80 \mathrm{~m}$ sub-bottom, velocities measured on dark gray, organic-rich carbonates ranged from 2500 to $3000 \mathrm{~m} / \mathrm{s}$. Velocities from more indurated limestones from the same depths averaged $3000-3500 \mathrm{~m} / \mathrm{s}$. Between 80 and $109.6 \mathrm{~m}$ sub-bottom, velocity values average $3500 \mathrm{~m} / \mathrm{s}$, with the samples recovered being limestone and marl. At $99.2 \mathrm{~m}$ sub-bottom, low velocities of $2400 \mathrm{~m} / \mathrm{s}$ were measured from an organic-rich layer.

\section{Wet-Bulk Density, Porosity, and Dry Water Content}

Wet-bulk density was measured by gravimetric and volumetric methods where possible and by 2 -min Gamma Ray Attenuation Porosity Evaluator (GRAPE) counts when sample recovery 
Table 3. X-ray analyses of samples from Holes $635 \mathrm{~A}$ and $635 \mathrm{~B}$.

\begin{tabular}{|c|c|c|c|c|c|}
\hline $\begin{array}{l}\text { Sub-bottom } \\
\text { depth } \\
\text { (m) }\end{array}$ & $\begin{array}{c}\text { Calcite } \\
(\%)\end{array}$ & $\begin{array}{l}\text { Aragonite } \\
(\%)\end{array}$ & $\begin{array}{c}\text { Dolomite } \\
(\%)\end{array}$ & $\begin{array}{c}\text { Quartz } \\
(\%)\end{array}$ & Comments \\
\hline 3.2 & 15 & 82 & 3 & 0 & Hole 635A \\
\hline 3.7 & 95 & 0 & 5 & 0 & \\
\hline 6.5 & 100 & 0 & 0 & 0 & Illite-montmorillonite present \\
\hline 6.7 & 22 & 69 & 5 & 4 & $\begin{array}{l}\text { High-Mg calcite, } 38 \% \text {; low- } \\
\text { Mg calcite, } 62 \% \text {; marca- } \\
\text { site, kaolinite, and illite- } \\
\text { montmorillonite present }\end{array}$ \\
\hline 7.9 & 21 & 69 & 10 & 0 & $\begin{array}{l}\text { High-Mg calcite, } 52 \% \text {; low- } \\
\text { Mg calcite, } 48 \% \text {; illite- } \\
\text { montmorillonite present }\end{array}$ \\
\hline 14.0 & 98 & 0 & 2 & 0 & \\
\hline 22.9 & 66 & 29 & 2 & 5 & Pyrite present \\
\hline 70.6 & 96 & 0 & 2 & 2 & $\begin{array}{l}\text { Dark color; pyrite, albite, } \\
\text { and illite-montmorillon- } \\
\text { ite present }\end{array}$ \\
\hline 71.2 & 100 & 0 & 0 & 0 & Illite-montmorillonite present \\
\hline 72.3 & 93 & 0 & 6 & 1 & Dark gray color \\
\hline 81.6 & 94 & 0 & 4 & 2 & Illite-montmorillonite present \\
\hline 83.4 & 96 & 0 & 3 & 0 & $\begin{array}{l}\text { Light color; illite-montmoril- } \\
\text { lonite present }\end{array}$ \\
\hline 89.6 & 90 & 0 & 7 & 3 & Illite-montmorillonite present \\
\hline 90.9 & 97 & 0 & 3 & 0 & Light color \\
\hline 91.4 & 96 & 0 & 2 & 2 & $\begin{array}{l}\text { Pyrite and illite-montmoril- } \\
\text { lonite present }\end{array}$ \\
\hline 91.9 & 97 & 0 & 3 & 0 & \\
\hline 99.4 & 97 & 0 & 2 & 1 & $\begin{array}{l}\text { Pyrite and illite-montmoril- } \\
\text { lonite present }\end{array}$ \\
\hline 101.1 & 95 & 0 & 5 & 0 & \\
\hline 101.7 & 99 & 0 & 0 & 1 & \\
\hline 108.9 & 91 & 0 & 5 & 4 & $\begin{array}{l}\text { Dark color; pyrite, micro- } \\
\text { cline, and illite-montmo- } \\
\text { rillonite present }\end{array}$ \\
\hline 111.2 & 98 & 0 & 0 & 2 & $\begin{array}{l}\text { Light color; pyrite, micro- } \\
\text { cline, and palygorskite(?) } \\
\text { present }\end{array}$ \\
\hline
\end{tabular}

dictated non-destructive measurements. When both techniques were used on the same sample, the results were within $4 \%$ of each other. Only the predominant lithology recovered in each core was sampled. Wet-bulk density within the top $3.7 \mathrm{~m}$ subbottom was low, between 1.61 and $1.87 \mathrm{~g} / \mathrm{cm}^{3}$. Between 3.7 and $32.4 \mathrm{~m}$, where grainstones were the primary lithology, density values range from 2.24 to $2.42 \mathrm{~g} / \mathrm{cm}^{3}$. The density values below $30 \mathrm{~m}$ sub-bottom show a gradual increase with depth from 1.78 to $2.39 \mathrm{~g} / \mathrm{cm}^{3}$ (Fig. 16).

Water content was measured with the pycnometer only, resulting in fewer water-content measurements than density measurements. Porosity was measured using both the pycnometer and GRAPE. Water content and porosity curves follow a similar trend (Fig. 16). In the upper $14 \mathrm{~m}$ sub-bottom, water content and porosity decrease drastically from $69 \%$ and $74 \%$ to $14 \%$ and $28 \%$, respectively. In Core $635 \mathrm{~B}-4 \mathrm{R}$, unlithified mudstone yielded a relatively high water content and porosity $(42 \%$ and $53 \%$ ). Below this depth, water content and porosity decrease to $11 \%$ and $24 \%$, respectively.

\section{Discussion}

From 7 to $61 \mathrm{~m}$ sub-bottom, where lithified rock of variable lithology predominates, the scatter in the data is dependent on the lithology and degree of consolidation of samples being measured. It is highly likely that in this interval only pebbles of canyon rubble or parts of a slump have been recovered. Below $61 \mathrm{~m}$ sub-bottom, a continuous section of mid-Cretaceous limestone was penetrated, and the average values of physical properties within this interval are similar to values found in the other holes deeper than $350 \mathrm{~m}$. This suggests that perhaps sediments below $61 \mathrm{~m}$ of Hole 635B may have been buried under up to $350 \mathrm{~m}$ of overburden at some earlier time.

\section{SEISMIC STRATIGRAPHY}

Both Sites 635 and 636 were modifications of BAH-3-A, designed to sample the inferred top of the shallow-water platform where it was buried by only $100-200 \mathrm{~m}$ of overburden. In Hole $635 \mathrm{~B}$, the upper $61 \mathrm{~m}$ of the overlying section proved to be slumps and debris flows, as suggested by seismic line 334 . From 61 to $117.7 \mathrm{~m}$ sub-bottom, marly limestones of late Albian-earliest Cenomanian age are present. These limestones were not directly predicted by the available seismic data, but they could account for low-amplitude impedance contrasts discernible in the canyon fill on line 334 .

Unfortunately, neither site succeeded in sampling the elusive platform, leaving open the possibility that the velocity discontinuity associated with this acoustic horizon $(2.87 \mathrm{~km} / \mathrm{s}$ above to $4.89 \mathrm{~km} / \mathrm{s}$ below) is locally produced by something other than a transition to shallow-water carbonates (e.g., a regional diagenetic event).

\section{SUMMARY AND CONCLUSIONS}

Both Sites 635 and 636 are near the canyon axis in Northeast Providence Channel (Great Bahama Canyon of Andrews et al., 1970). The objective of Sites 635 and 636 was to reach the seismic reflector beneath the canyon floor interpreted as the drowned top of a Cretaceous carbonate platform (Sheridan et al., 1981). Only Hole 635B achieved significant penetration; Holes 635A and $636 \mathrm{~A}$ merely added some detail to the stratigraphy of the top $20 \mathrm{~m}$.

The sequence in Hole 635B consists of the following units (Fig. 17 and "Sedimentology" and "Biostratigraphy" sections, this chapter): (1) Unit I, periplatform ooze and foraminiferpteropod sand, late Pleistocene-Holocene, $2.3 \mathrm{~m}$; (2) Unit II, 


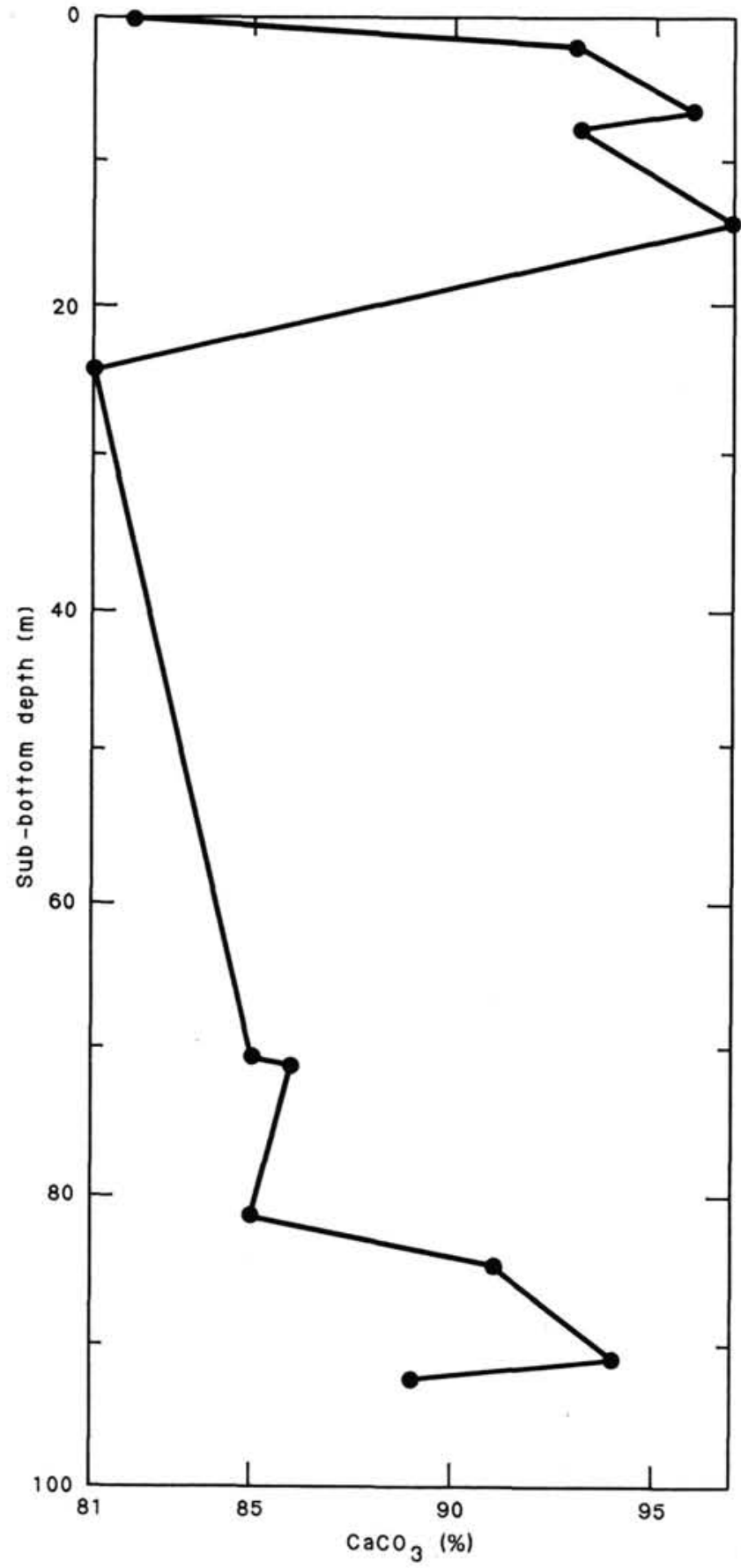

Figure 11. Carbonate-bomb data, Site 635.

calcareous ooze and chalk of Pliocene and Pleistocene age with rudstones and floatstones (debris flows and turbidites?) of $\mathrm{Ce}$ nomanian-Turonian and Miocene age; no orderly succession of ages and no undisturbed contacts between different lithologies were observed; $59 \mathrm{~m}$; and (3) Unit III, slightly argillaceous chalk and limestone with alternations of dark, organic-rich and light, carbonate-rich intervals; intercalations of muddy debris flows and small slumps, late Albian, $57 \mathrm{~m}$.
Table 4. Carbonatebomb data, Site 635 .

\begin{tabular}{cc}
\hline $\begin{array}{c}\text { Sub-bottom } \\
\text { depth } \\
(\mathrm{m})\end{array}$ & $\begin{array}{c}\mathrm{CaCO}_{3} \\
\text { content } \\
(\%)\end{array}$ \\
\hline 0.25 & 82 \\
2.0 & 93 \\
6.5 & 96 \\
7.6 & 93 \\
14.0 & 97 \\
24.1 & 81 \\
70.6 & 85 \\
71.2 & 86 \\
81.5 & 85 \\
84.5 & 91 \\
90.9 & 94 \\
92.4 & 89 \\
\hline
\end{tabular}

Based on borehole data and seismic profiles, Unit II is interpreted as one or several slump masses, probably derived from the northern flank of the canyon and emplaced in the Late Tertiary and veneered by pelagic sediment of Unit I. Unit III is in place and consists of bathyal and near-bottom neritic carbonates with a slight terrigenous component of clay, quartz, and terrestrial organic matter ("Sedimentology," "Biostratigraphy," "Inorganic Geochemistry," and "Organic Geochemistry" sections, this chapter). Alternations of organic-rich and lean intervals on a scale of 10 to $40 \mathrm{~cm}$ may reflect short-term fluctuations of oxygen levels common in this period (e.g., Buffler, Schlager, et al., 1984, Site 540, for coeval deposits in the Gulf of Mexico). Some of the Unit III rocks resemble the Cenomanian marls at Site 627. However, the age overlap between the two formations is small, if any. Unit III is generally older than Unit V at Site 627.

At Site 635 , a prominent seismic reflector with a change in interval velocity from 2.9 to $4.9 \mathrm{~km} / \mathrm{s}$ lies $70-90 \mathrm{~m}$ below the total depth of Hole 635B. As at Site 627, this reflector may indicate the top of a drowned carbonate platform. Unfossiliferous sucrosic dolomite was dredged from below this reflector on the canyon walls approximately $10 \mathrm{~km}$ east of Site 635 (Corso, 1983). The presence of bathyal carbonates of late Albian age at Site 635 implies that platform drowning in this area was probably earlier than at Site 627 but well within the late Aptian to Cenomanian interval of global platform drowning (Schlager, 1981).

Organic-rich layers in Unit III contain up to about $6 \%$ organic carbon. The organic matter is partly gas-prone (terrestrial) and partly oil-prone (algal) kerogen that is approaching maturity.

\section{REFERENCES}

Andrews, J. E., Shepard, F. P., and Hurley, R. J., 1970. Great Bahama Canyon. Geol. Soc. Am. Bull., 81:1061-1078.

Buffler, R. T., Schlager, W., et al., 1984. Init. Repts. DSDP, 77: Washington (U.S. Govt. Printing Office).

Corso, W., 1983. Sedimentology of rocks dredged from Bahamian Platform slopes [M.S. thesis]. Univ. Miami.

Gartner, S., 1977. Calcareous nannofossil biostratigraphy and revised zonation of the Pleistocene. Mar. Micropaleontol., 2:1-25.

Schlager, W., 1981. The paradox of drowned reefs and carbonate platforms. Geol. Soc. Am. Bull., 92:197-211.

Sheridan, R. E., Crosby, J. T., Bryan, G. M., and Stoffa, P. L., 1981. Stratigraphy and structure of southern Blake Plateau, northern Florida Straits, and northern Bahama Platform from multichannel seismic reflection data. AAPG Bull., 65:2571-2593. 


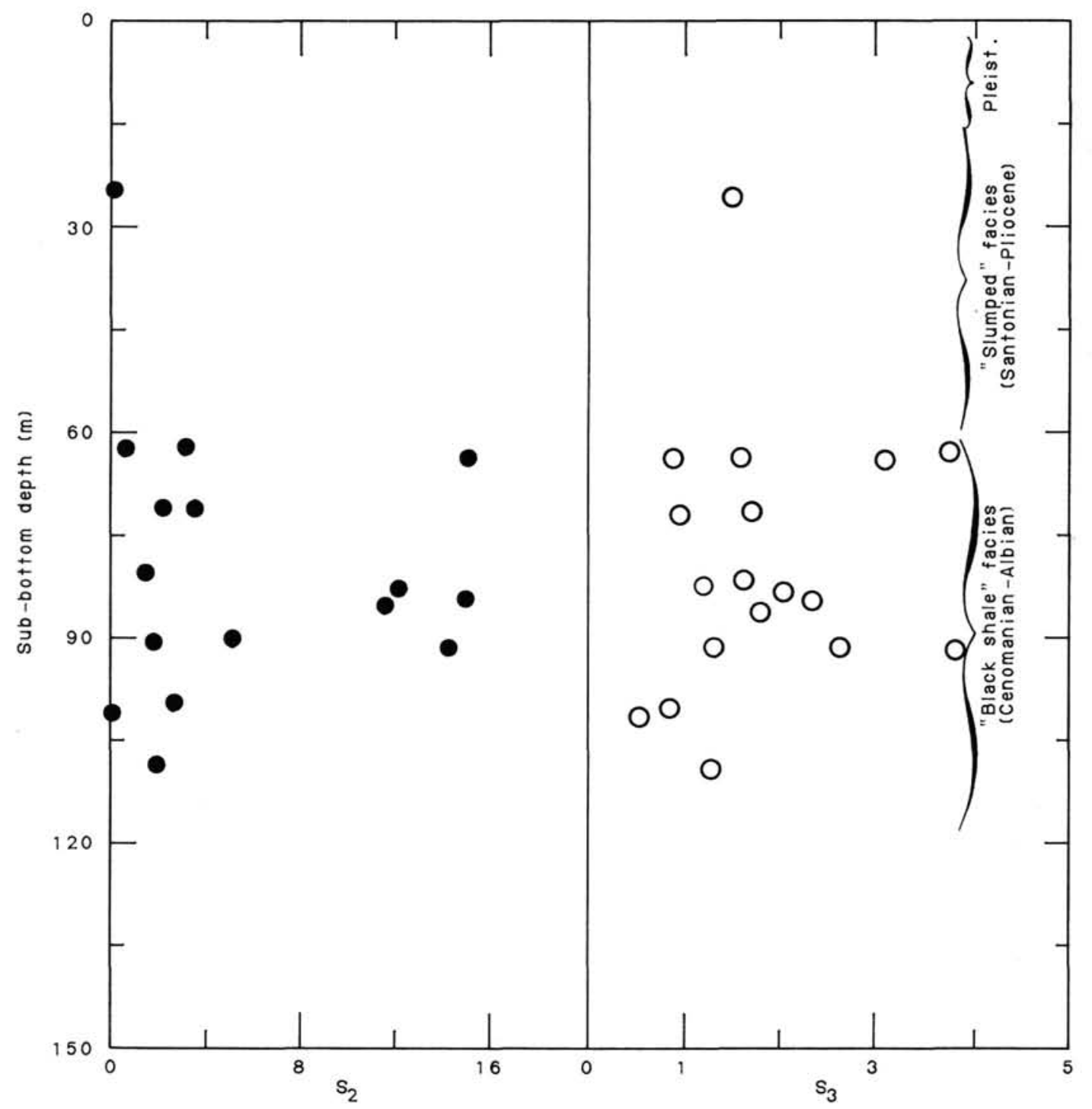

Figure 12. $S_{2}$ and $S_{3}$ content of sediments from Hole 635B. 

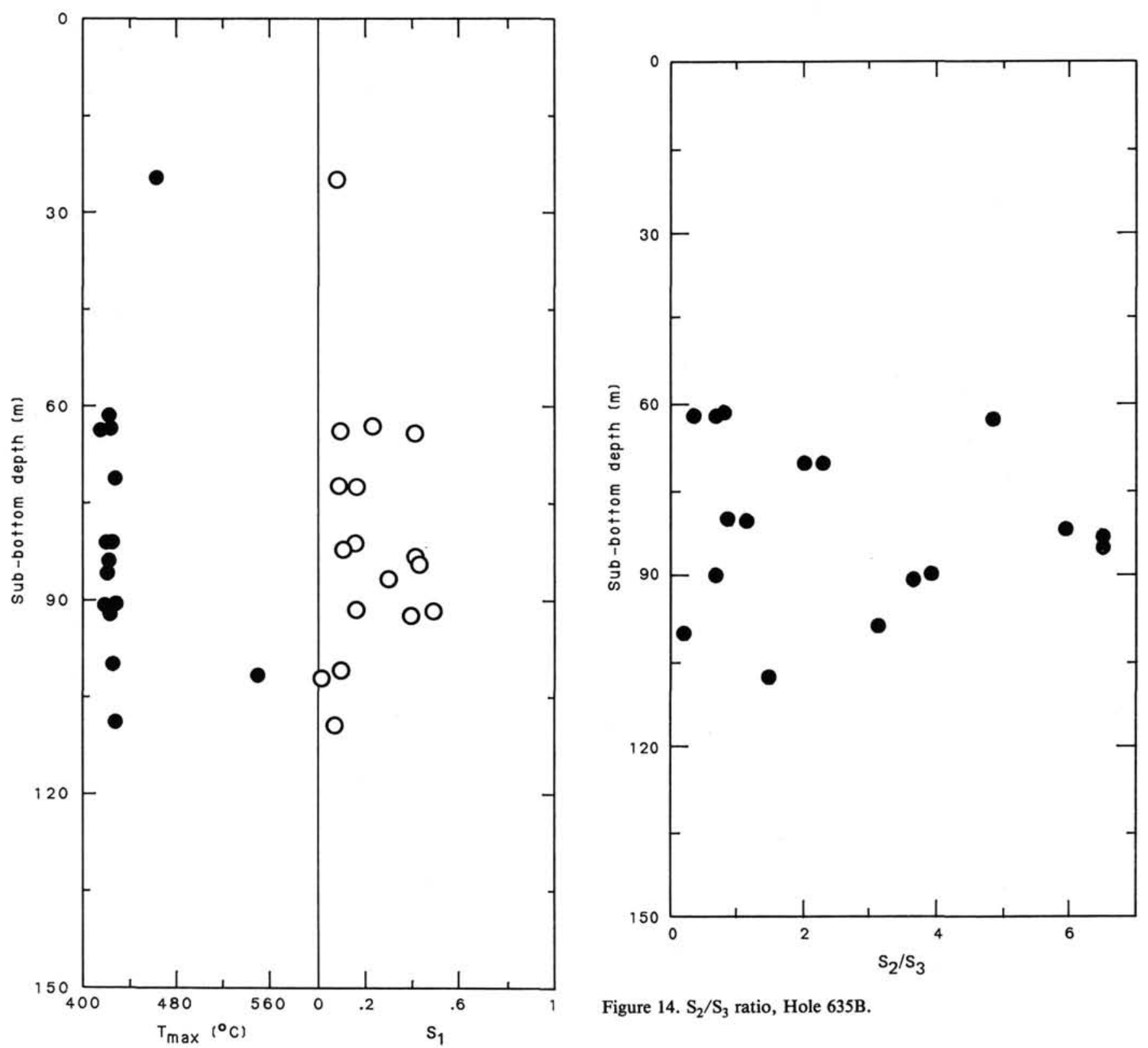

Figure 14. $\mathrm{S}_{2} / \mathrm{S}_{3}$ ratio, Hole 635B.

Figure 13. $\mathrm{T}_{\max }$ and $\mathrm{S}_{1}$ values, Hole 635B. 

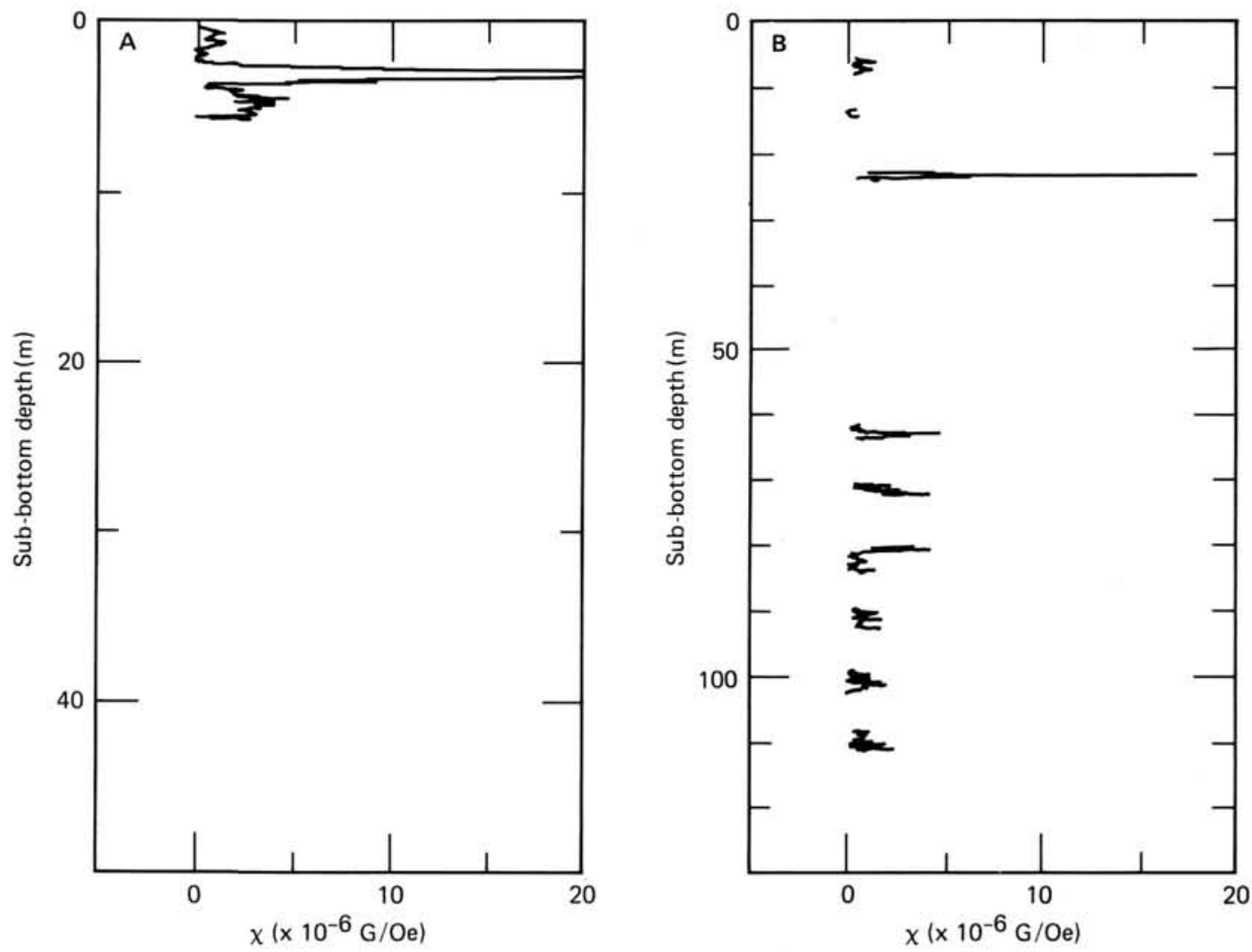

Figure 15. Magnetic-susceptibility values $\left(\times 10^{-6} \mathrm{G} / \mathrm{Oe}\right)$ plotted vs. depth for Holes $635 \mathrm{~A}(\mathrm{~A})$ and $635 \mathrm{~B}(\mathrm{~B})$. 
Table 5. Physical properties of sediments, Site 635.

\begin{tabular}{|c|c|c|c|c|c|c|c|c|}
\hline $\begin{array}{c}\text { Sample } \\
\text { (level in } \mathrm{cm} \text { ) }\end{array}$ & $\begin{array}{l}\text { Sub-bottom } \\
\text { depth } \\
\text { (m) }\end{array}$ & $\begin{array}{l}\text { Velocity }^{a} \\
(\mathrm{~m} / \mathrm{s})\end{array}$ & $\begin{array}{c}\text { Velocity } \\
\text { in liner } \\
(\mathrm{m} / \mathrm{s})\end{array}$ & $\begin{array}{c}\text { Wet-bulk } \\
\text { density } \\
\left(\mathrm{g} / \mathrm{cm}^{3}\right)\end{array}$ & $\begin{array}{l}\text { Dry water } \\
\text { content } \\
(\%)\end{array}$ & $\begin{array}{c}\text { Porosity } \\
(\%)\end{array}$ & $\begin{array}{c}\text { Thermal } \\
\text { conductivity } \\
\left(10^{-3} \times \text { cal } \times{ }^{\circ} \mathrm{C}^{-1}\right. \\
\left.\times \mathrm{cm}^{-1} \times \mathrm{s}^{-1}\right)\end{array}$ & $\begin{array}{l}\text { Shear } \\
\text { strength } \\
\text { (kPa) }\end{array}$ \\
\hline \multicolumn{9}{|l|}{ Hole $635 \mathrm{~A}$} \\
\hline $\begin{array}{l}1-1,75 \\
1-1,100 \\
1-2,70 \\
2-1,75 \\
2-1,110 \\
2-2,80 \\
3-1 \\
3, \text { CC }\end{array}$ & $\begin{array}{r}0.8 \\
1.0 \\
\\
3.5 \\
3.9 \\
5.1 \\
10.6 \\
20.1\end{array}$ & $\begin{array}{l}35.37 \\
43.60 \\
46.07\end{array}$ & $\begin{array}{l}1419 \\
1720\end{array}$ & $\begin{array}{l}1.66 \\
1.87 \\
1.79 \\
\\
1.88 \\
1.74 \\
2.20 \\
2.56 \\
2.41\end{array}$ & $\begin{array}{l}64.29 \\
50.23 \\
37.89 \\
55.45\end{array}$ & $\begin{array}{l}65.00 \\
59.87 \\
51.53 \\
62.13\end{array}$ & $\begin{array}{l}2.161 \\
2.350 \\
2.260 \\
2.270\end{array}$ & $\begin{array}{l}5.02 \\
7.28 \\
1.26 \\
\\
2.51\end{array}$ \\
\hline \multicolumn{9}{|l|}{ Hole 635B } \\
\hline $\begin{array}{l}1-1,30 \\
1-1,75 \\
1-2,50 \\
1-3,70 \\
2-1,92\end{array}$ & $\begin{array}{l}0.3 \\
0.7 \\
2.0 \\
3.7 \\
6.5\end{array}$ & $\begin{array}{l}3440 \text { (b) } \\
2970 \text { (c) }\end{array}$ & $\begin{array}{l}1627 \\
1631\end{array}$ & $\begin{array}{l}1.61 \\
1.63 \\
1.87 \\
2.25 \\
2.23\end{array}$ & $\begin{array}{l}73.75 \\
\\
70.78 \\
36.10 \\
16.01\end{array}$ & $\begin{array}{l}68.88 \\
68.01 \\
49.34 \\
30.58\end{array}$ & & $\begin{array}{l}2.26 \\
1.00 \\
1.51 \\
6.03\end{array}$ \\
\hline $2-2,55$ & 7.6 & $\begin{array}{l}3478 \text { (b) } \\
3556 \text { (c) }\end{array}$ & & $\begin{array}{l}2.42 \\
2.25\end{array}$ & 15.62 & 32.22 & & \\
\hline $3-1,72$ & 14.0 & $\begin{array}{l}3494 \text { (b) } \\
3486 \text { (c) }\end{array}$ & & $\begin{array}{l}2.32 \\
2.22\end{array}$ & 13.84 & 27.79 & & \\
\hline $4-1,130$ & 24.1 & & & 1.78 & 42.35 & 52.88 & & 7.28 \\
\hline $\begin{array}{l}5-1,5 \\
5, \mathrm{CC} \\
7\end{array}$ & $\begin{array}{l}32.4 \\
61.0\end{array}$ & $\begin{array}{l}3896 \\
5102 \\
4221\end{array}$ & & & & & & \\
\hline $8-1,10$ & 61.1 & 2903 & & & & & & \\
\hline $8-1,70$ & 61.7 & 3970 & & 2.24 & & & & \\
\hline $8-2,5$ & 62.5 & 2544 & & 2.26 & & & & \\
\hline $\begin{array}{l}8-2,35 \\
8, C C\end{array}$ & 62.8 & 3397 & & $\begin{array}{l}2.19 \\
2.32\end{array}$ & 12.84 & 26.07 & & \\
\hline $9-1,25$ & 70.8 & 2942 & & & & & & \\
\hline $\begin{array}{l}9-1,60 \\
9-1,75\end{array}$ & $\begin{array}{l}71.2 \\
71.3\end{array}$ & $\begin{array}{l}2304 \text { (?) } \\
2993\end{array}$ & & 2.35 & 11.26 & 23.44 & & \\
\hline $\begin{array}{l}10-1,131 \\
10-3,36\end{array}$ & $\begin{array}{l}81.5 \\
83.6\end{array}$ & $\begin{array}{l}3267 \\
3536 \text { (c) } \\
3889 \text { (b) }\end{array}$ & & $\begin{array}{l}2.28 \\
2.36 \\
2.26\end{array}$ & $\begin{array}{l}14.95 \\
13.96\end{array}$ & $\begin{array}{l}29.21 \\
28.49\end{array}$ & & \\
\hline $11-1,135$ & 91.0 & $\begin{array}{l}3623 \text { (c) } \\
3647 \text { (b) }\end{array}$ & & $\begin{array}{l}2.26 \\
2.31\end{array}$ & 14.32 & 27.98 & & \\
\hline $11-2,87$ & 92.0 & $\begin{array}{l}3846 \\
3852\end{array}$ & & $\begin{array}{l}2.39 \\
2.28\end{array}$ & 11.46 & 24.18 & & \\
\hline $12-1,116$ & 99.2 & $\begin{array}{l}2464 \text { (c) } \\
2320 \text { (a) }\end{array}$ & & 2.35 & & & & \\
\hline $13-1,130$ & 109.6 & 3345 (a) & & & & & & \\
\hline $13-1,140$ & 109.7 & & & 2.31 & & & & \\
\hline
\end{tabular}

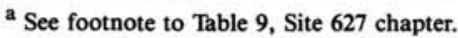




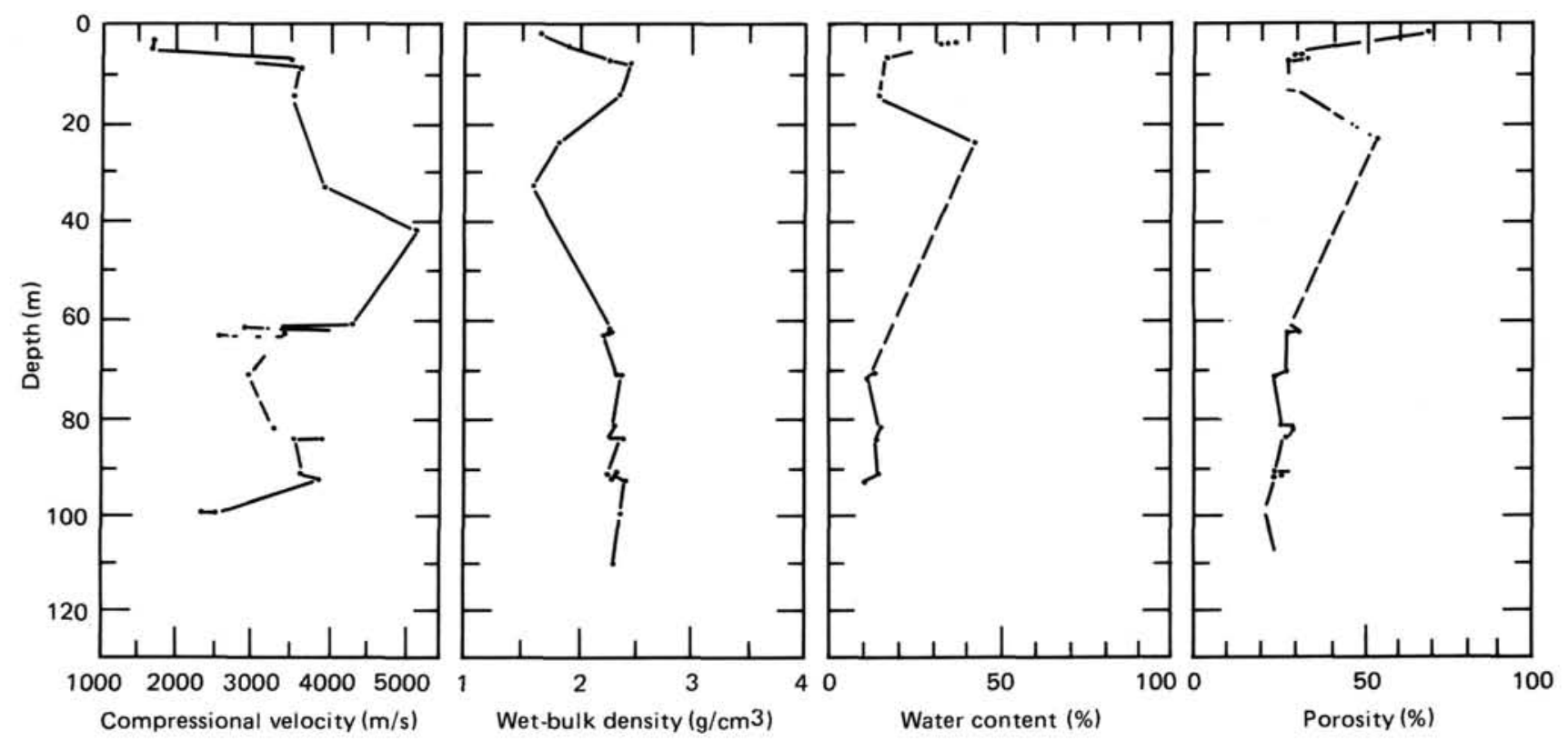

Figure 16. Graphic representation of physical-property data from sediments in Hole 635B. 


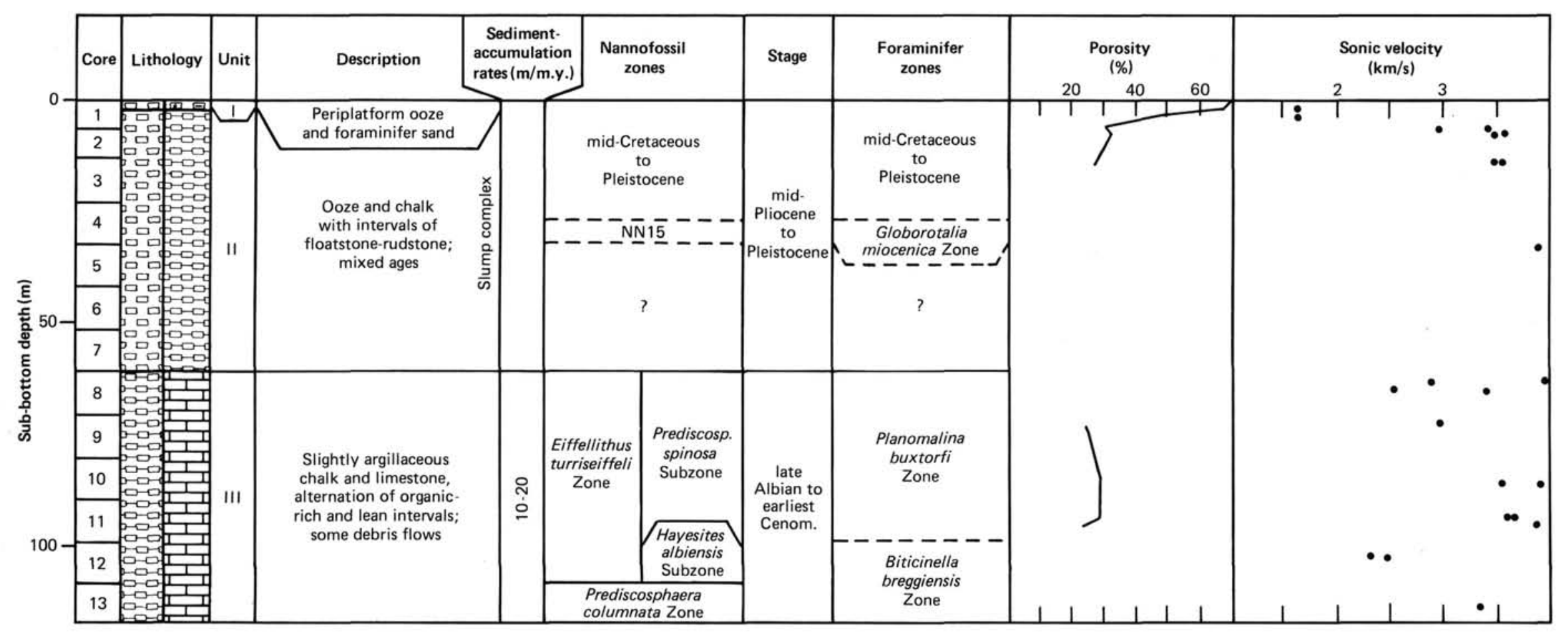

Figure 17. Summary of data for Site 635. 


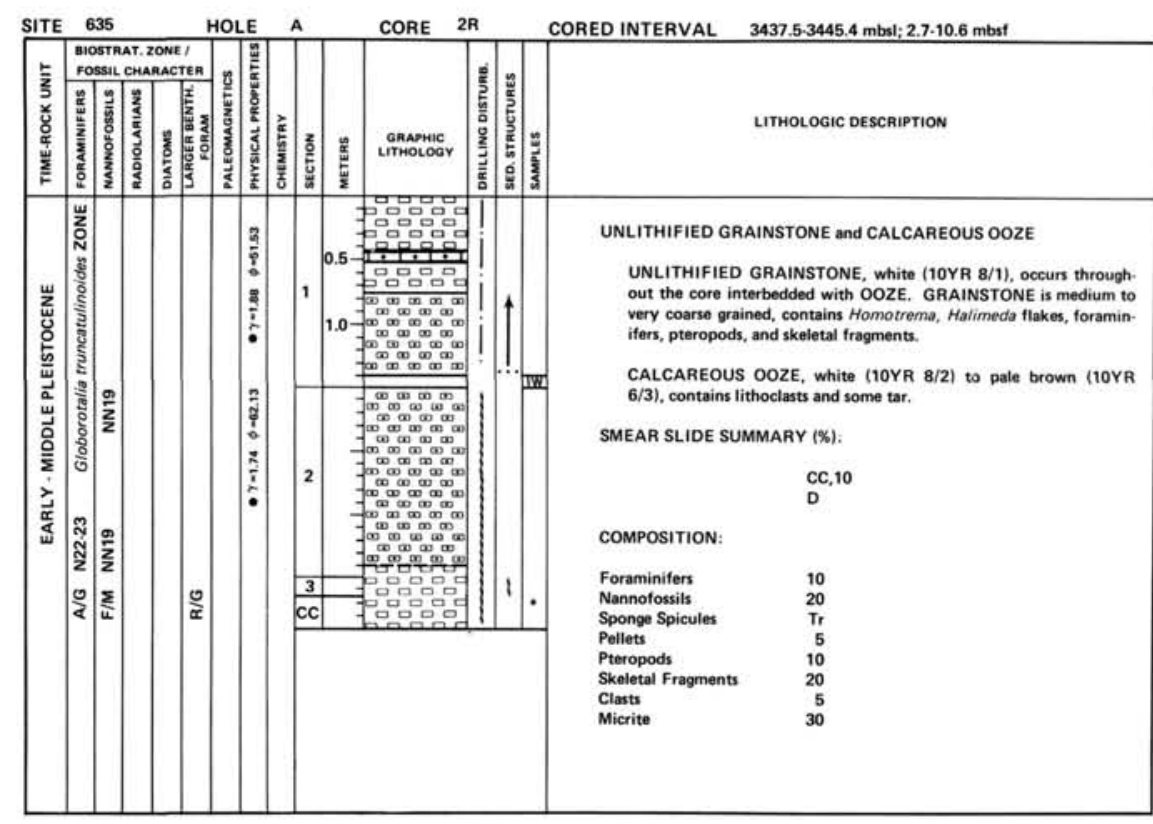

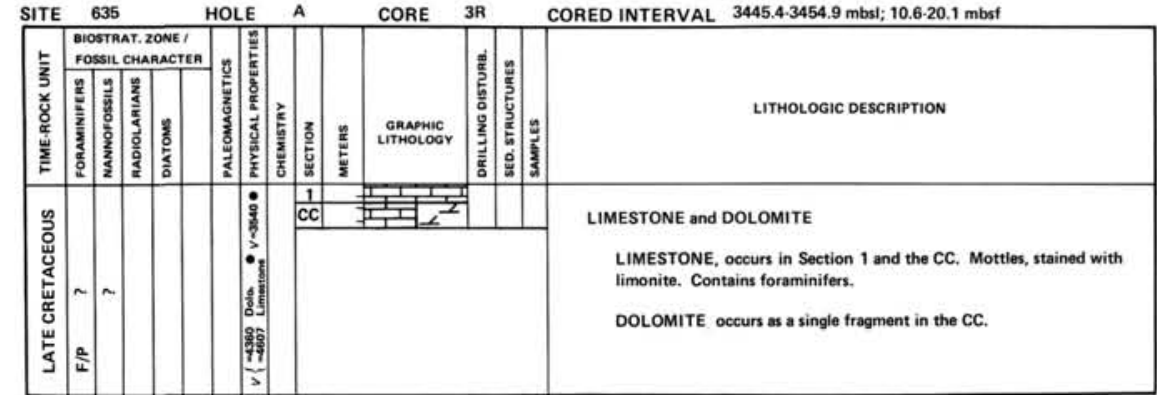




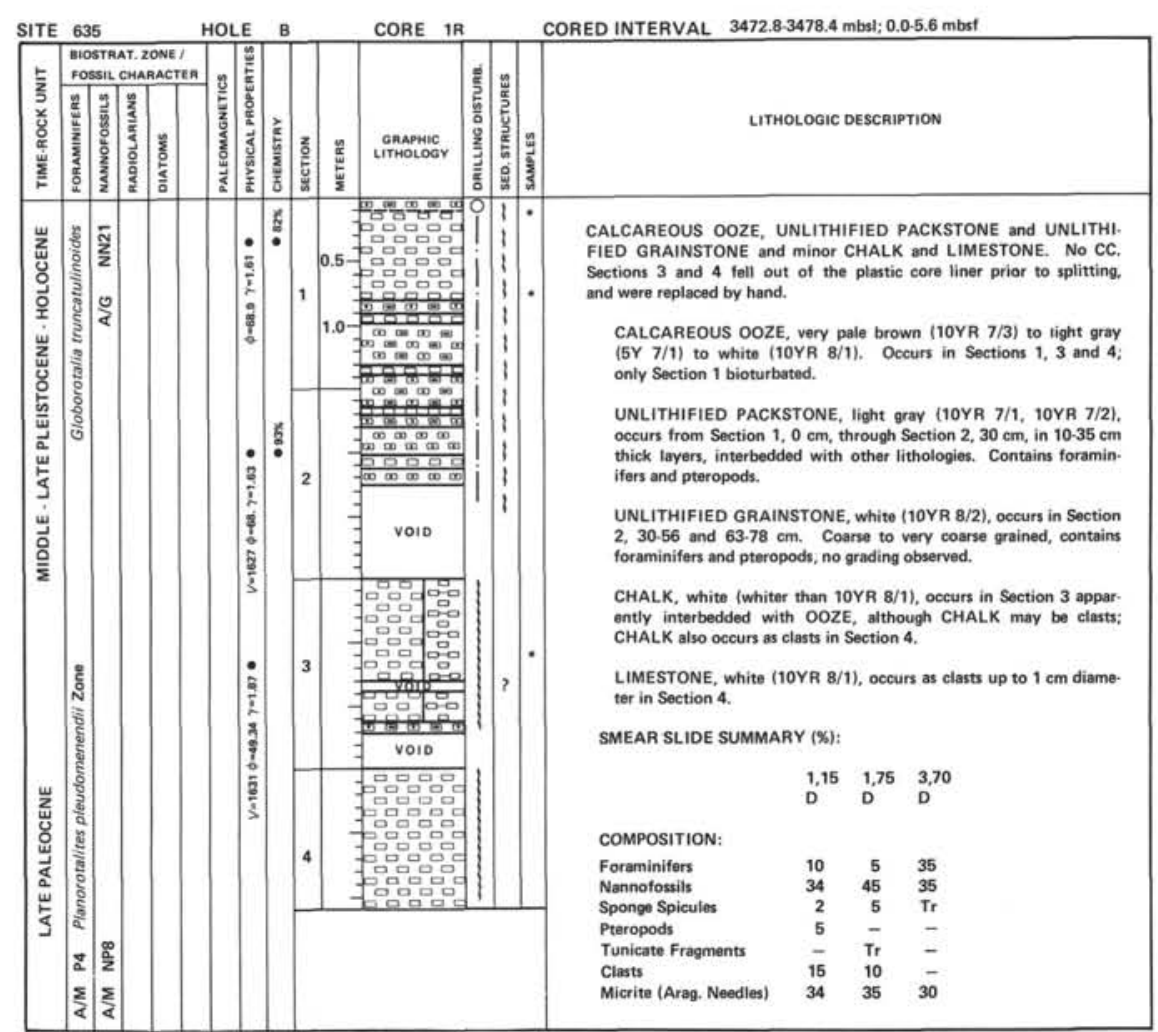

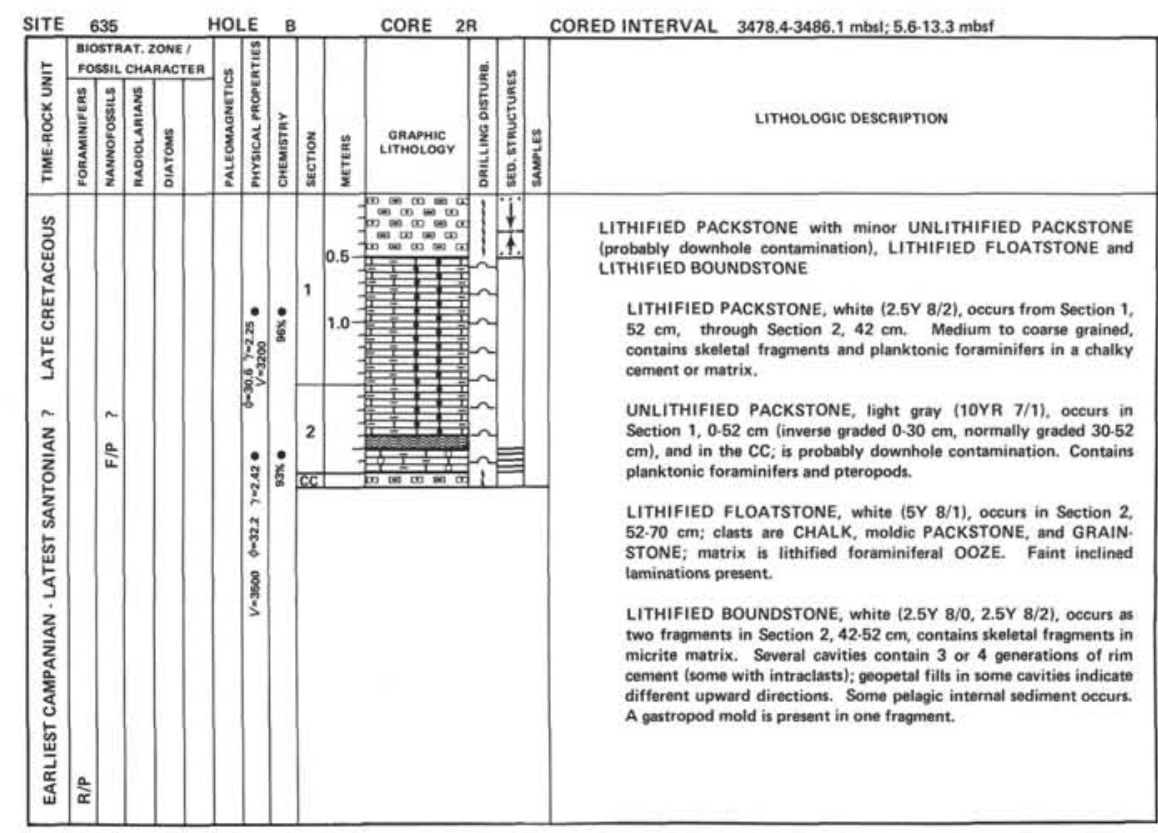

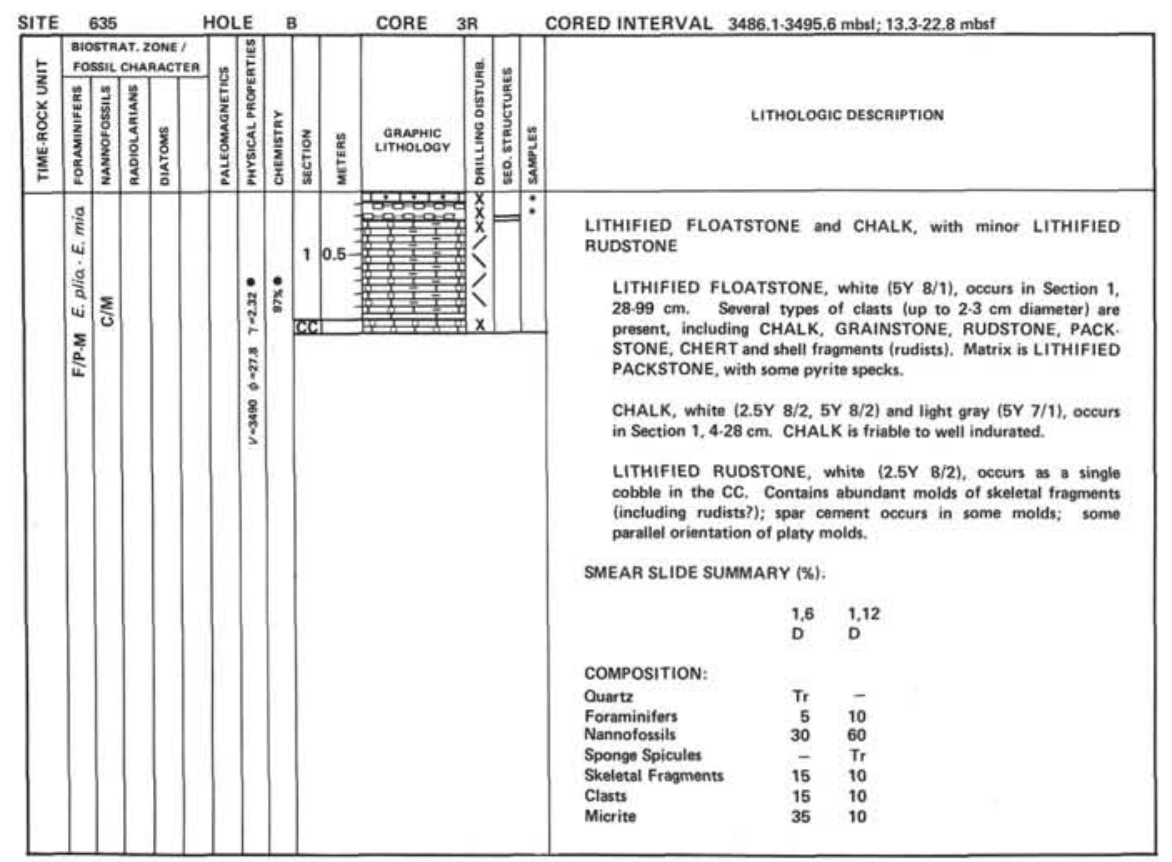



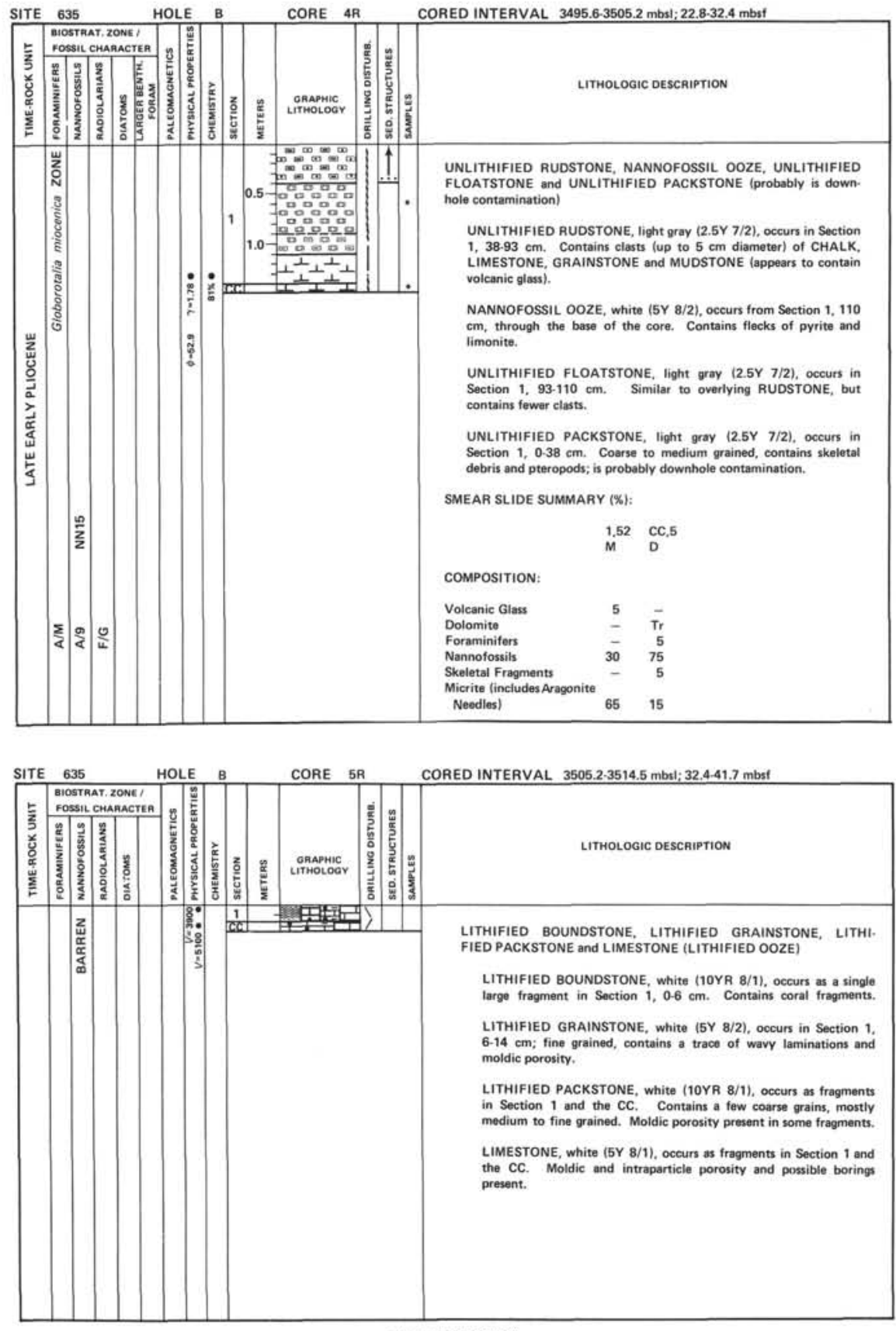
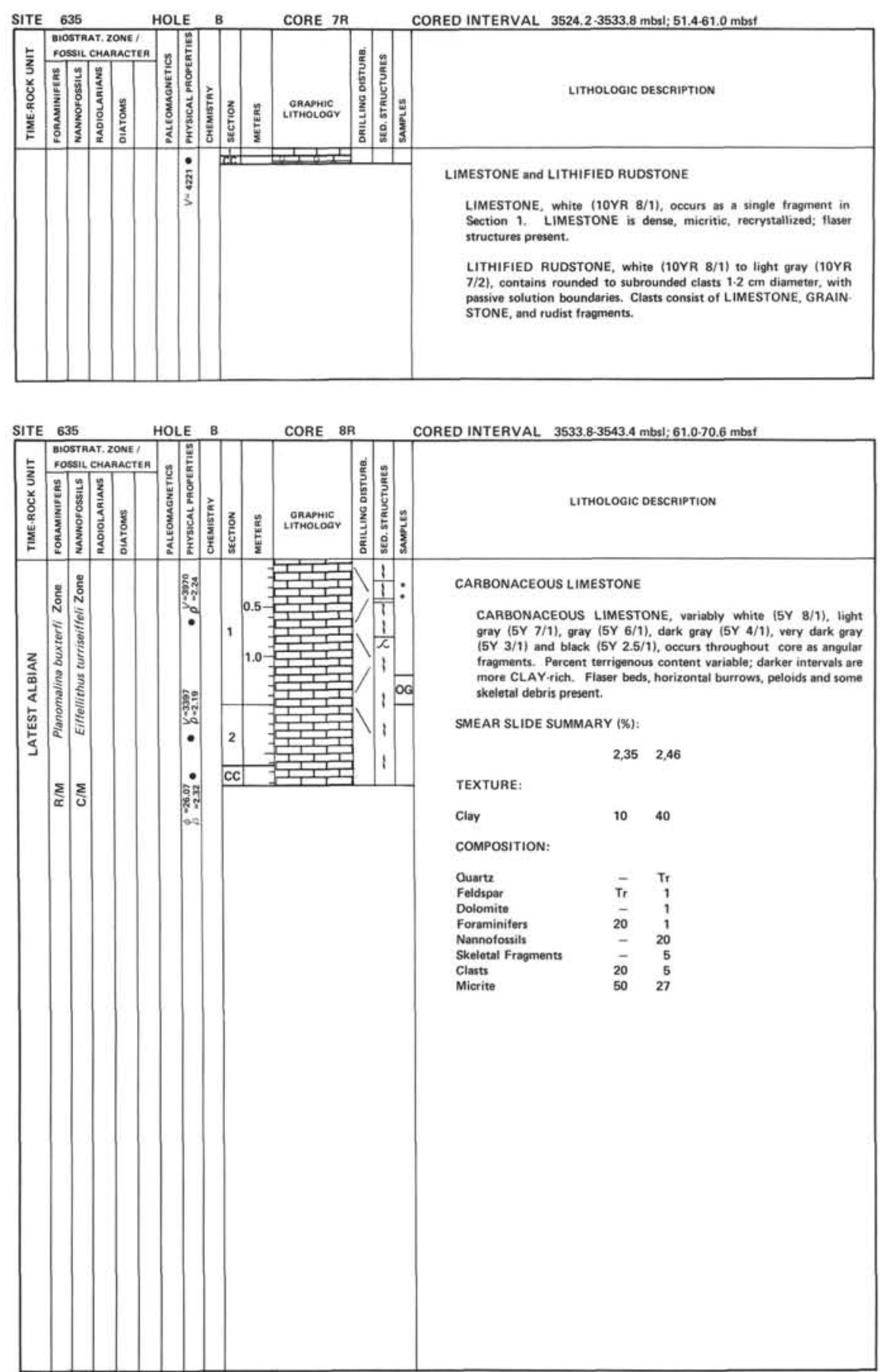


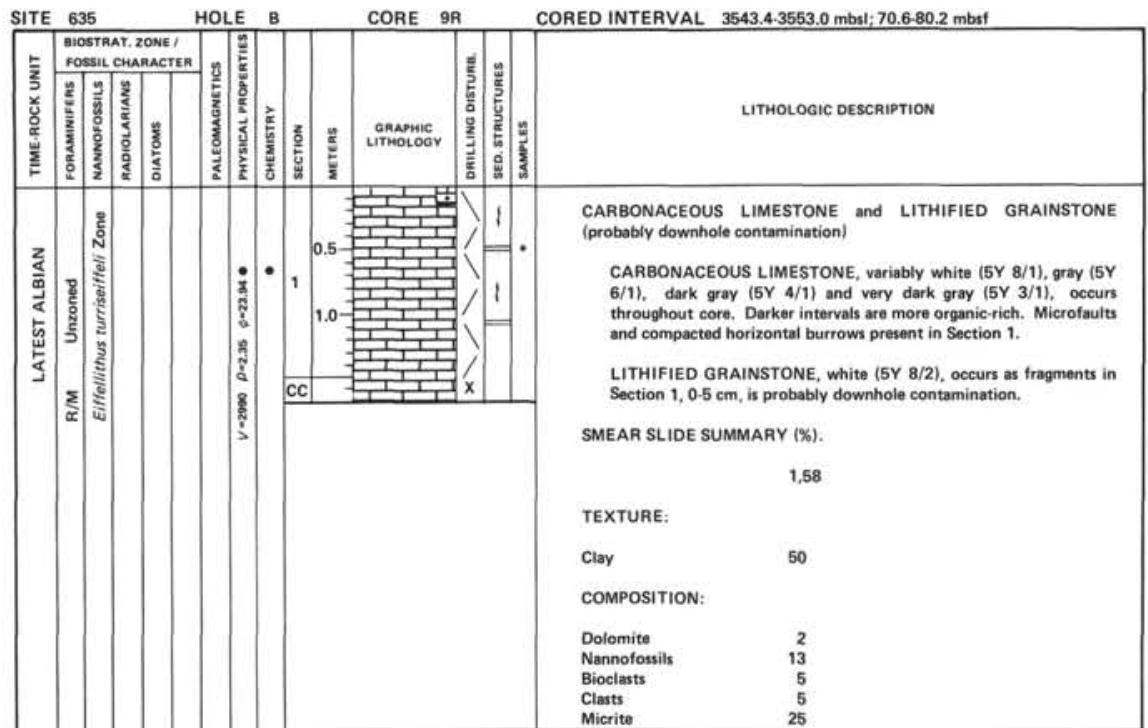




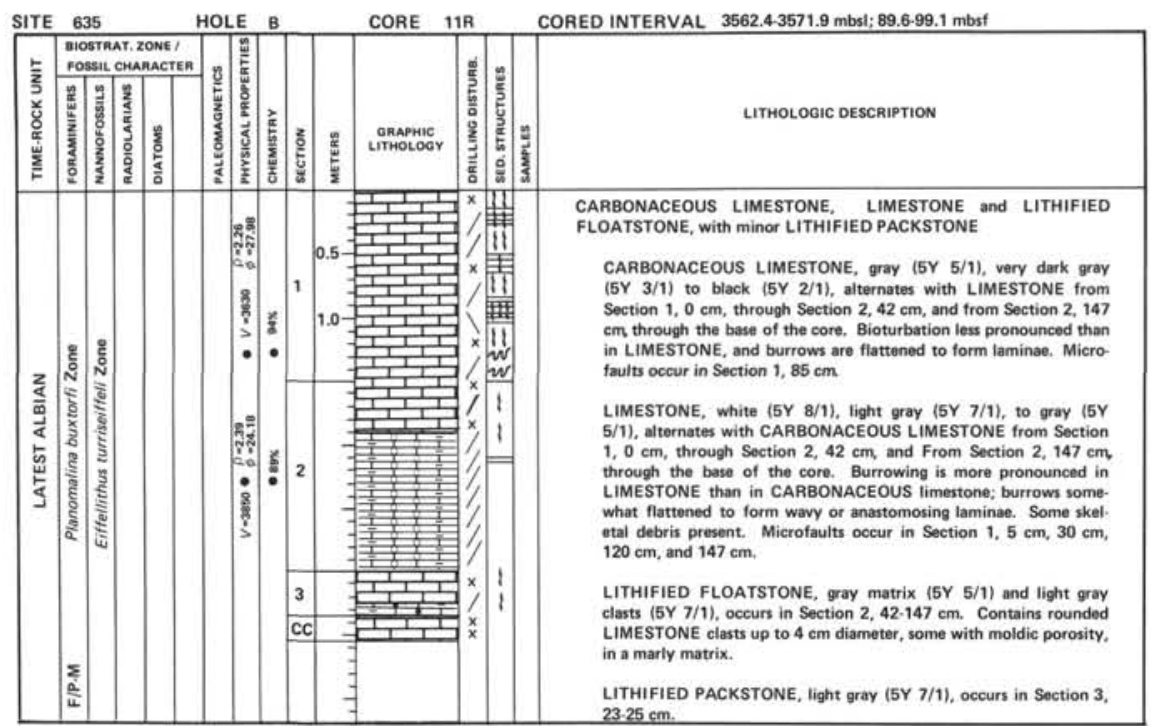

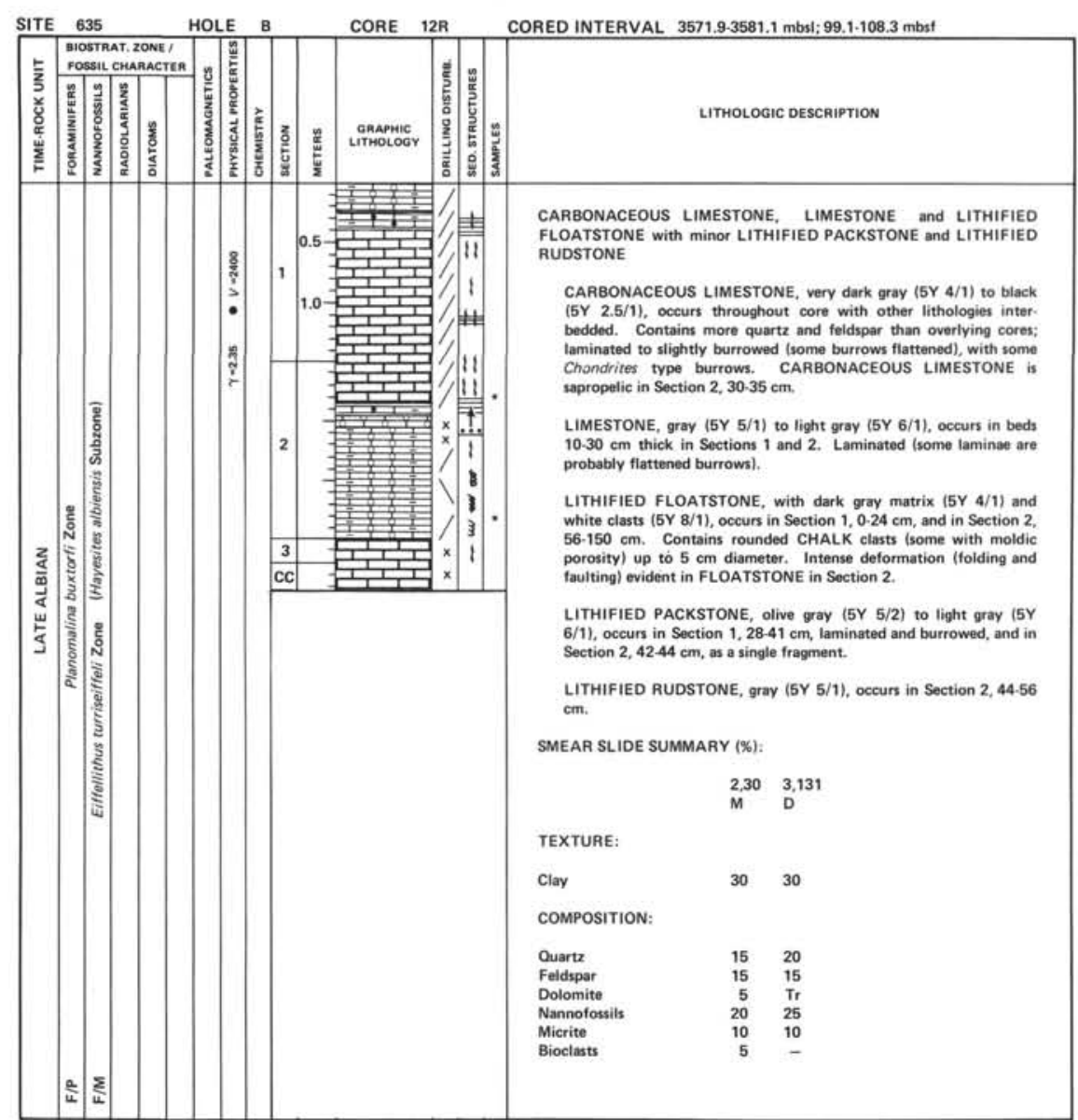




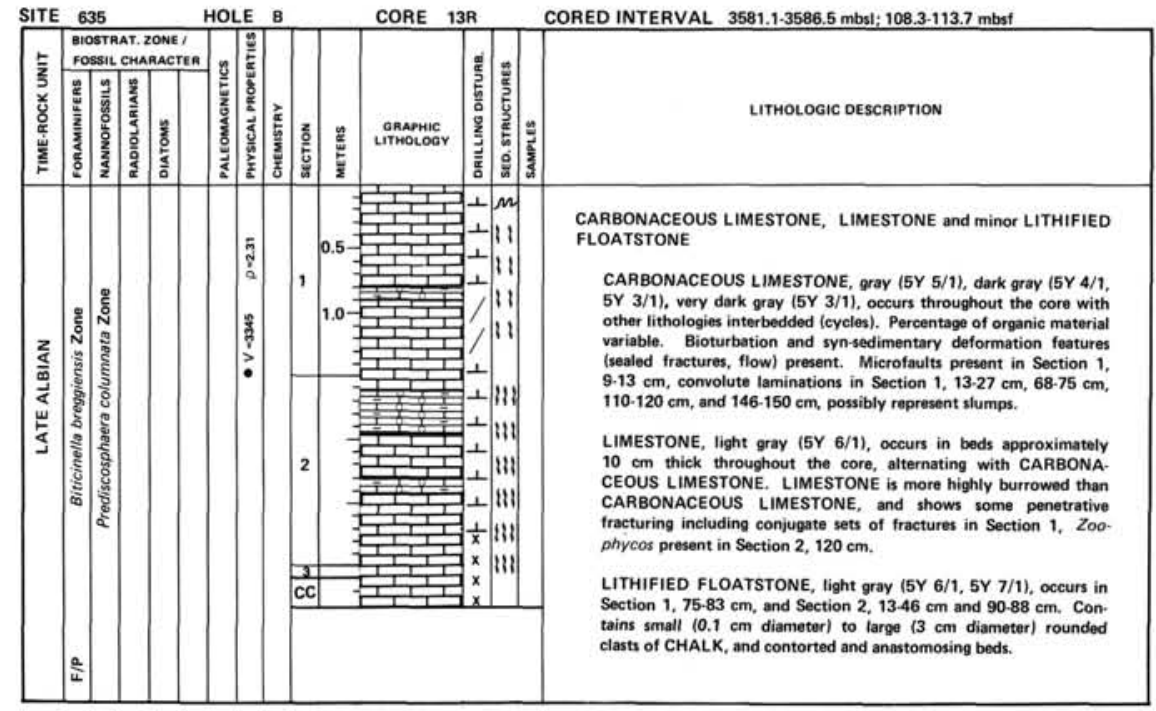

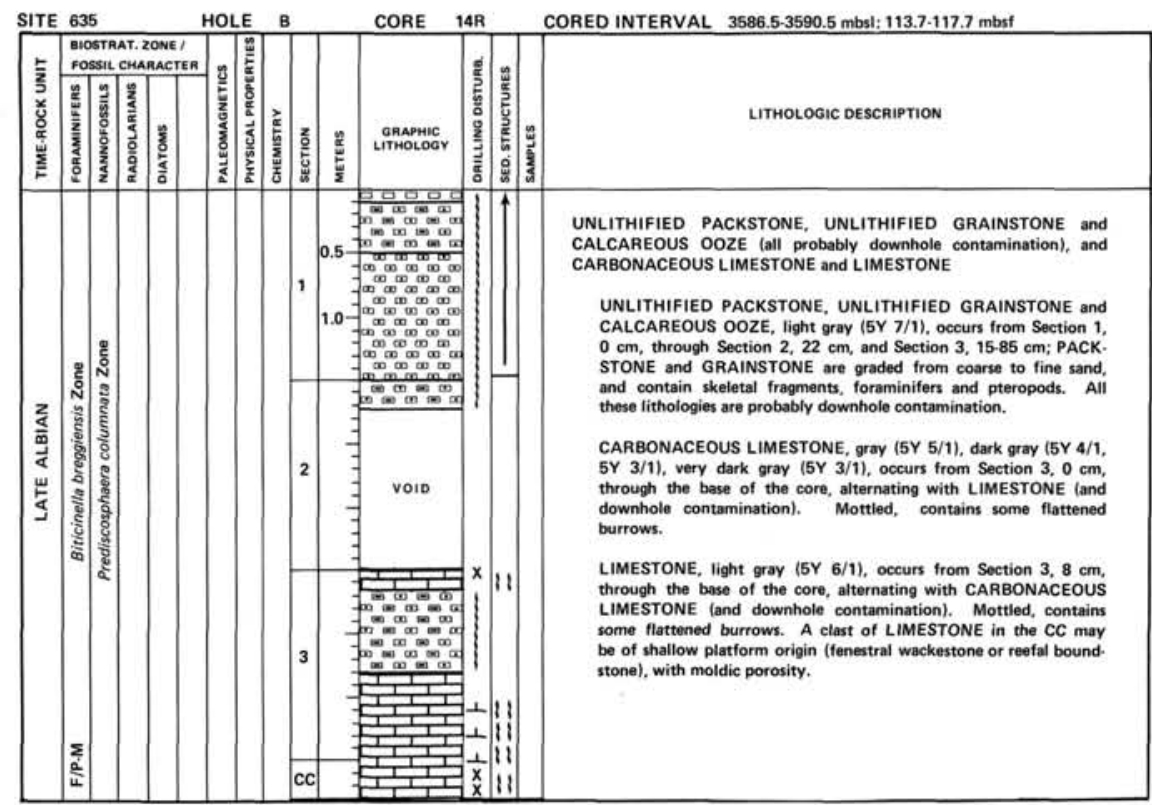




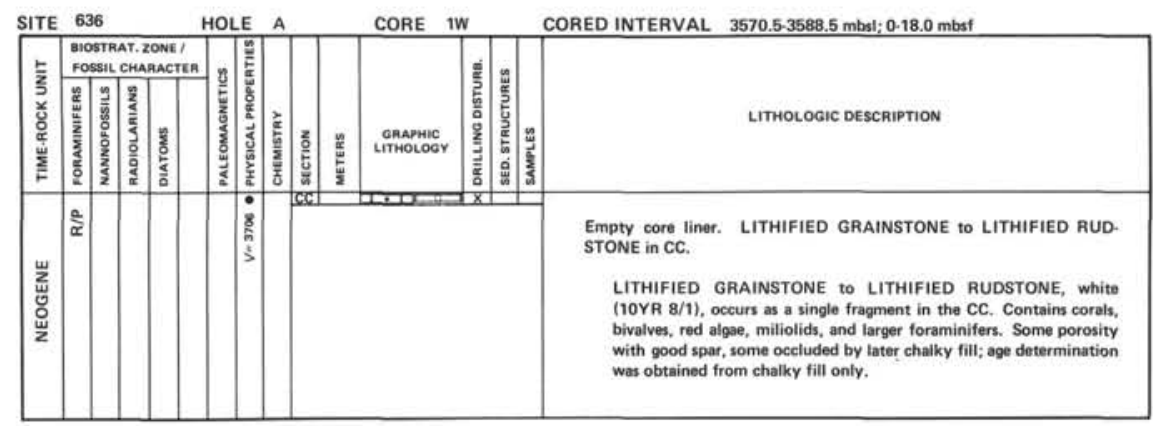

\begin{tabular}{|c|c|c|c|c|c|c|c|c|c|}
\hline SITE & & & & OLE & & & CORE 2R & & CORED INTERVAL $3588.535591 .5 \mathrm{mbs} ; 18.0-21.0 \mathrm{mbst}$ \\
\hline & $\begin{array}{l}\text { DostrinA } \\
\text { rosssile }\end{array}$ & . & & & & & & & \\
\hline 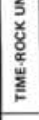 & 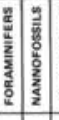 & 总 & & & & \begin{tabular}{|l|l} 
\\
$\frac{2}{2}$ \\
\end{tabular} & 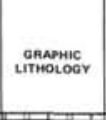 & 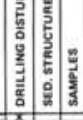 & LITHOLOGIC DESCRIPTION \\
\hline $\begin{array}{l}\frac{w}{w} \\
\text { w. } \\
\frac{w}{2}\end{array}$ & & & & & & & & & 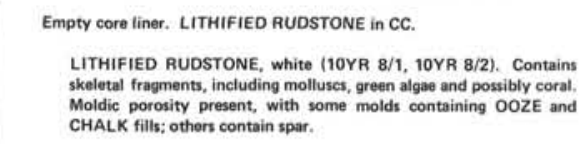 \\
\hline$\frac{d}{\alpha}$ & & & & & & & & & \\
\hline
\end{tabular}




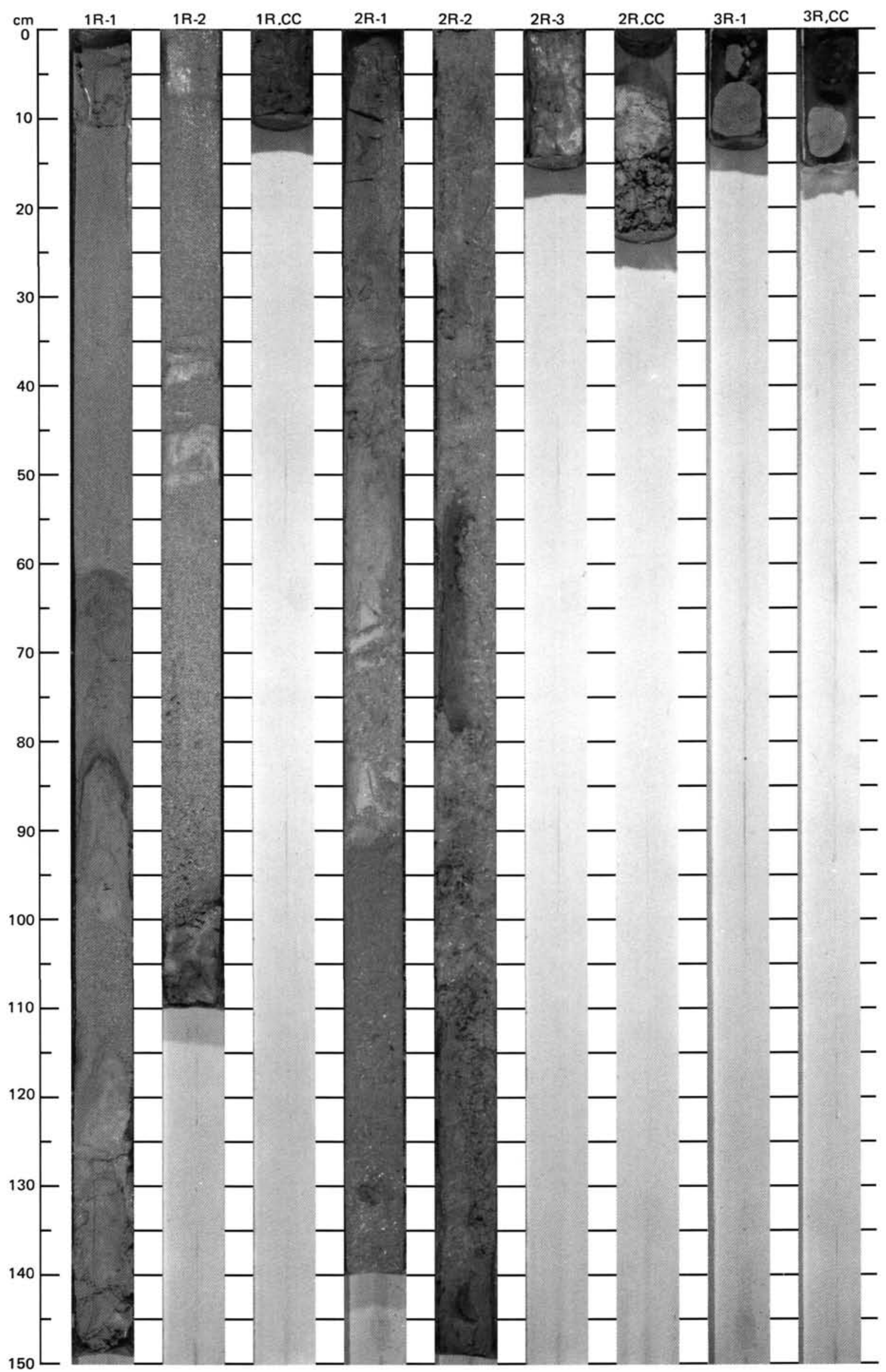


SITE 635 (HOLE B)

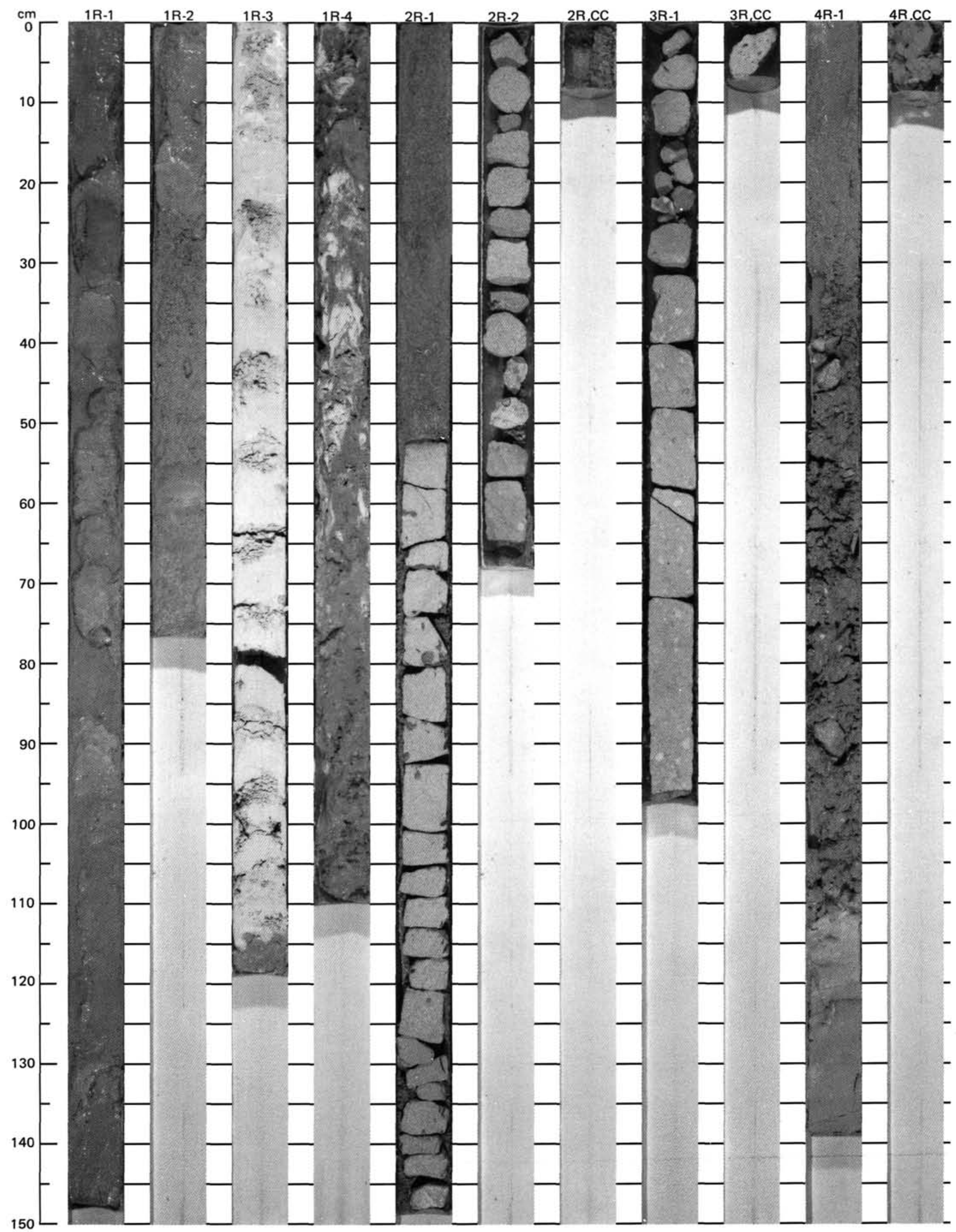




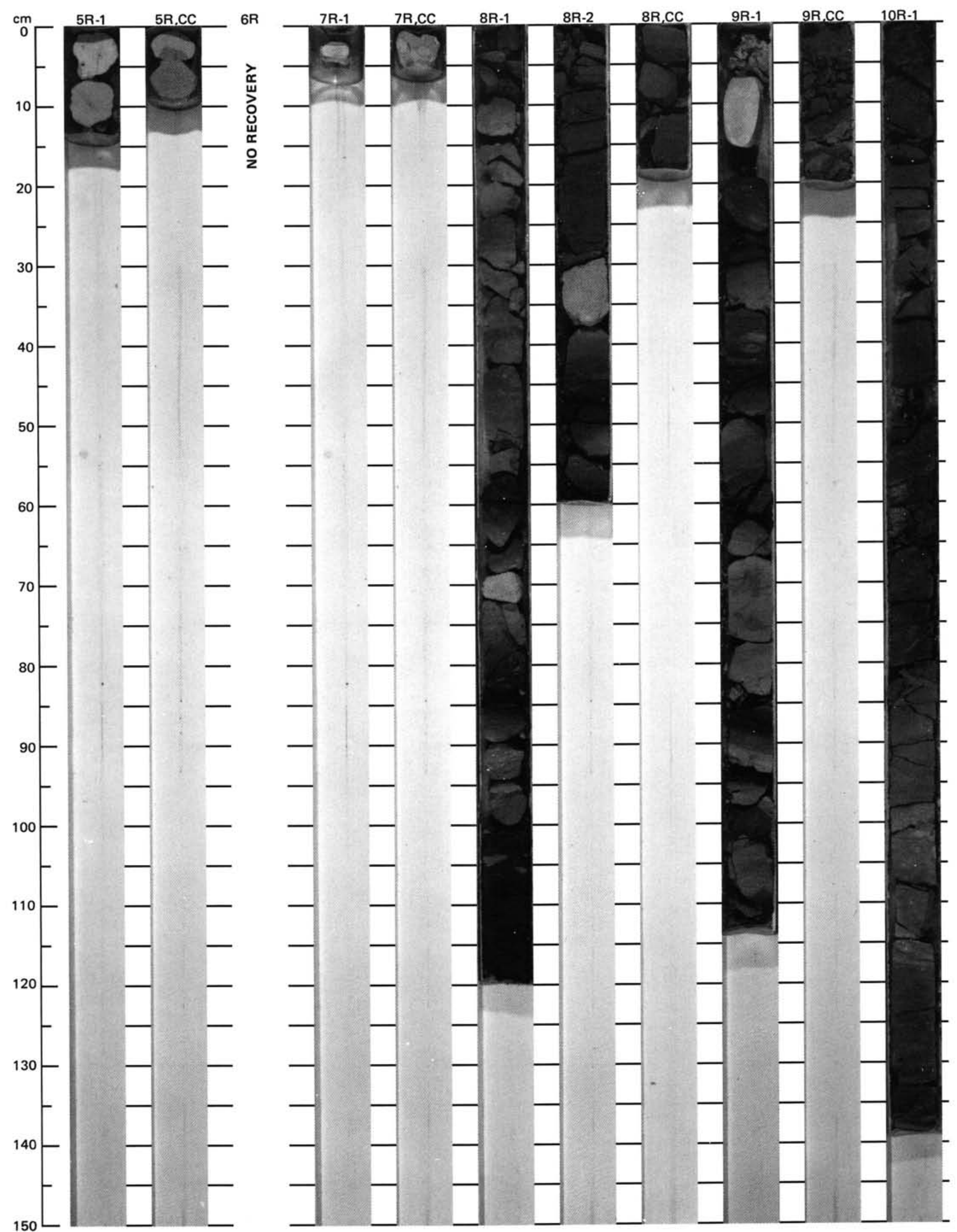


SITE 635 (HOLE B)

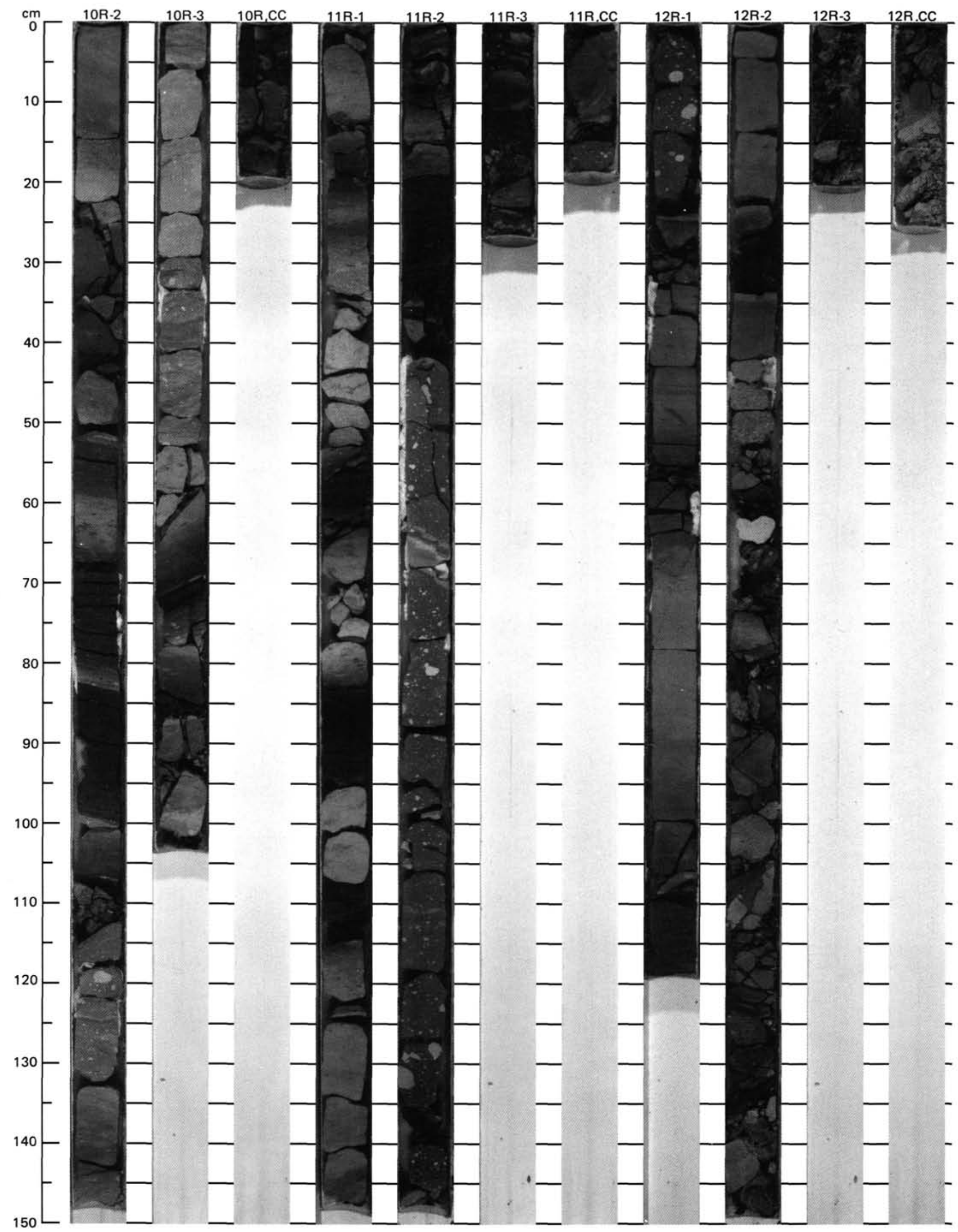




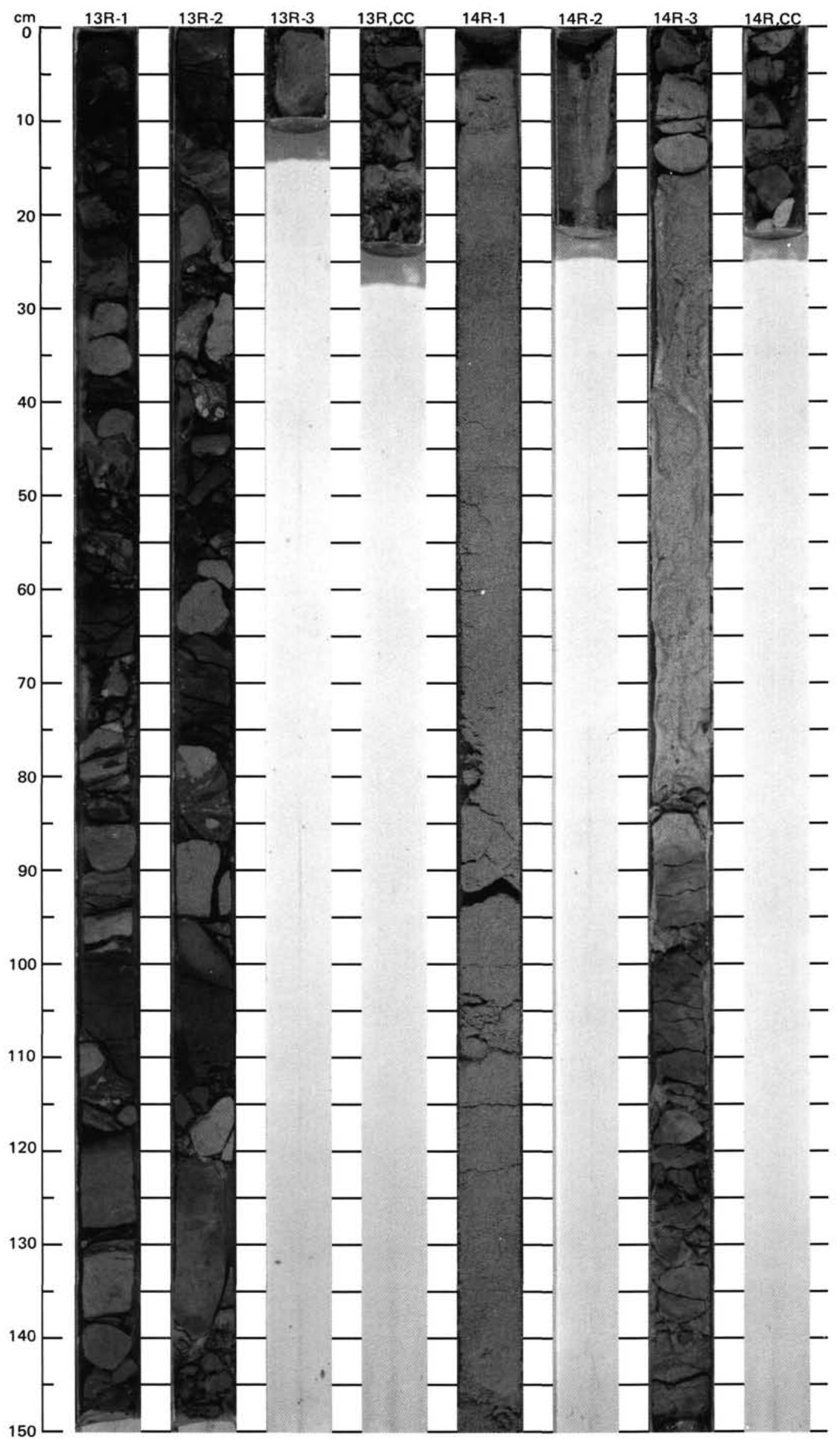


